\title{
Bitter flavour in dairy products. I. A review of the factors likely to influence its development, mainly in cheese manufacture
}

\author{
L Lemieux, RE Simard \\ Université Laval, pavillon Paul-Comtois, centre de recherche STELA, \\ département de sciences et technologie des aliments, Sainte-Foy, Québec, Canada, G1K 7P4
}

(Received 11 May 1990; accepted 23 August 1991)

\begin{abstract}
Summary - Following a definition of bitterness and a mention of the link between the bitterness of peptides and their content of hydrophobic amino acid residues, a detailed description is given of the numerous factors likely to influence the development of bitter off-flavour defect in dairy products with emphasis on cheese. Factors such as milk quality, $\mathrm{pH}$, psychrotrophic bacteria, fat and mineral content, the cheese manufacturing process including the cooking temperature, salt concentration and manner of draining the curd, the acidity or the $\mathrm{pH}$ of cheese, and sanitary processing and hygienic packaging conditions are less important than bacterial proliferation in the cheese vat and the type and amount of starter and rennet used. The major roles played by these last three factors are better understood since the development of the aseptic vat technique. Finally, possible ways are mentioned of keeping the concentration of bitter peptides below the threshold level for bitter taste detection.
\end{abstract}

bitterness / dairy product / cheese / peptide / hydrophobicity

Résumé - L'amertume dans les produits laițiers. I. Une revue des facteurs susceptibles d'influencer son apparition, principalement au cours de la fabrication fromagère. Après avoir défini l'amertume et mentionné la relation existant entre l'amertume des peptides et leur contenu en acides aminés hydrophobes, les nombreux facteurs susceptibles d'influencer l'apparition du défaut d'amertume dans les produits laitiers sont décrits en détail. Les facteurs tels que la qualité du lait, son $\mathrm{pH}$, son contenu en bactéries psychrotrophes, en matière grasse et en minéraux, le mode de fabrication du fromage et la température de cuisson, l'acidité ou le pH du fromage, les conditions sanitaires de transport du lait, de fabrication et d'emballage du produit fini sont moins importantes que la prolifération bactérienne dans le bac à fromage et que le type et la quantité de ferment et de présure utilisés. La compréhension du rôle joué par ces 3 derniers facteurs a été rendue possible avec l'avènement de la technique de fabrication aseptique du fromage. Pour terminer, sont mentionnés d'éventuels moyens de conserver la concentration en peptides amers au-dessous du seuil de détection de l'amertume.

amertume / produit laitier / fromage / peptide / hydrophobicité 


\section{INTRODUCTION}

Taste buds, which are located in papillae on the tongue, can detect the characteristic taste of food determined by the balance of the primary (sweet, sour, salt, bitter and umami) and/or secondary (astringent, metallic and hot) tastes (Nishimura and Kato, 1988; Cheftel et al, 1977). Umami is the characteristic taste of monosodium glutamate and 5'-ribonucleotides.

Sometimes desired and regarded as a typical flavour note (eg, in grapefruit) and in some cases indesirable and objected to as off-flavour (eg, in cheese), bitterness of foodstuffs may be caused either by naturally occurring bitter compounds or by products from chemical reactions that occur during storage or processing.

Characterised by a pleasant and slightly sweet taste, milk is very susceptible to flavour defects from a variety of sources (absorption of flavours, bacterial contamination and chemical reactions such as lipolysis (Charalambous, 1986)), and unless properly heat-treated and refrigerated, it has a very short shelf-life. For centuries cheese-making has been the only means of preserving the major constituents of milk, and among the variety of cheese types some can be considered as products with real long-term storage capabilities. The proteolytic activity of starter cultures produces bitterness in cheese. By this process, caseins are broken down into peptides of low molecular weight $(\sim 1400$ $\mathrm{Da}$ ) with bulky hydrophobic groups towards the C-terminal end of the peptide (Matoba and Hata, 1972). Peptide bitterness, caused by the hydrophobic property of the amino acid side chain, can be predicted from the rule proposed by Ney (1971, 1979).

Bitterness in yoghurt has been shown to be caused by the proteolytic activity of
Lactobacillus bulgaricus during storage (Renz and Puhan, 1975). Gelation and the occurrence of bitter flavour in UHT milk are caused by heat-stable proteases and lipolytic enzymes produced by psychrotrophic bacteria. However, milk processing temperature is critical; while appreciable amounts of lipase may be inactivated by heating milk at $64^{\circ} \mathrm{C}$ for $10 \mathrm{~s}$, heat treatments required to inactivate proteases also denature the milk proteins (Charalambous, 1986).

The greatest contribution to the intensity of cheese flavour has been shown to be present in the water-soluble fraction (McGugan et al, 1979). Bitterness is most intense in that fraction and has been attributed to medium sized (tri- to hexa-) peptides (Biede and Hammond, 1979) resulting from the enzymic digestion of casein. Beta-casein may be the source of bitter peptides produced by the proteinase(s) present in the cell wall of starter bacteria (Exterkate, 1976), while chymosin (rennet) may produce bitter peptides from all casein components (Exterkate, 1983).

Following the development of technology for the acceleration of the cheese ripening process (Fox, 1988-1989), development of low fat cheeses, improved shelflife, transformation of milk to new food products and alteration of milk components by use of recombinant DNA techniques (Muysson and Verrinder Gibbins, 1989), the dairy industry will have to find ways to avoid this potential defect of bitterness.

From the literature surveyed it is surprising to find that bitterness, although reported for all dairy products, has been studied most extensively in Cheddar and Gouda cheeses. This research has identified 20 factors related to bitter off-flavour which will be described in detail in this review. It is understandable that most of the text will be devoted to bitterness in cheese. 


\section{BITTERNESS-HYDROPHOBICITY}

Bitterness, a flavour defect which is encountered quite frequently in Cheddar and Gouda cheeses, results from the accumulation of bitter-tasting peptides formed by the action of proteolytic enzymes on casein (Fryer, 1969; Sardinas, 1972; Sullivan and Jago, 1972; Sullivan et al, 1973; Stadhouders, 1974; Stadhouders and Hup, 1975; Lawrence et al, 1976; Creamer, 1978). The bitter peptides have special chemical properties which enable them to interact with the taste buds at the back of the tongue to give the sensation of bitterness.

The existence in the bitter peptides of 2 bitter taste determinant sites which can bind to the bitter taste receptor has been proposed by Okai (1977), who also postulated that the hydrophobic residue of a peptide acts as a first binding site and in the presence of the second site, called the stimulating site, a bitter taste is detectable. However, the mechanism of the second site has not yet been resolved (Ishibashi et al, 1987).

The concentration of the bitter peptides in the cheese must exceed a certain threshold level before bitterness can be detected. The overall level of bitterness in cheese might be determined finally by the relative rates at which bitter peptides are formed and broken down to non-bitter products (Jago, 1974).

Early on it was suggested, based on the study of Emmons et al (1960b) on 132 cheeses, that cheese bitterness was due to unhydrolysed peptides. These authors obtained a correlation coefficient of 0.90 between the TCA-soluble N/amino $\mathrm{N}$ ratio, which is an estimate of the average number of amino groups per peptide in the TCA soluble extract, and the level of bitterness.
It is now accepted that the bitter flavour produced during enzymic hydrolysis of casein is due to particular types of peptides (Fujimaki et al, 1970). Ney (1971) was the first to propose the Q-hypothesis, a semi-quantitative relationship between the amino acid composition of a peptide and its bitterness. According to Ney (1979), no particular single amino acid or sequence was needed to impart the bitter taste. However, Japanese workers (eg, Shinoda et al, 1985, 1986a, b) proved later on, by synthesizing bitter peptides and several analogs, that the nature of the terminal amino acids and their steric parameters have some significance in the intensity of bitter taste.

\section{BITTER FLAVOUR DEVELOPMENT IN CHEESE}

Cheese-making, which is an important way of preserving the nutritive components of milk, is practised in various parts of the world. That explains why many different cheese varieties have been developed. However, the results obtained using one cheese variety with a particular milk coagulant cannot be extrapolated to another cheese variety or cheese made with a different milk coagulant. Modification of the cheese-making conditions and parameters (choice of starter, rennet concentration, cooking temperature and salt addition (Harwalkar and Elliott, 1971; Creamer, 1978) has helped in the study of cheese bitterness.

Bitter peptides are released from the casein molecules primarily by the action of the rennet and bacterial proteinases; a contribution may also be expected from bacterial peptidases, which may reduce the size of peptides initially too large to give a bitter taste (Sullivan and Jago, 1972; Sullivan et al, 1973). The production 
of bitter peptides during the process of enzymic digestion is not always unfavourable; indeed, a bitter taste is one of the important components of cheese taste quality (Shinoda et al, 1985; 1986b). However, when bitter peptides accumulate, their concentration may exceed the flavour threshold for bitterness and can limit acceptance of the cheese, which will then be rated bitter (Visser et al, 1983b, c). It should be noted that this threshold is considered to increase with the age of a cheese because of the increase in other flavour components (Creamer, 1979).

Bitterness has long been recognised as a major defect in Gouda (Visser et al, 1983b) and Cheddar cheeses (Emmons et al, 1962a; Richardson and Creamer, 1973; Hamilton et al, 1974; Crawford, 1977; Champion and Stanley, 1982; Edwards and Kosikowski, 1983), but it also occurs in Camembert and similar types of cheeses produced in France (Pélissier et al, 1974; Mourgues et al, 1983). This defect has also been reported in Swiss mountain cheese (Guigoz and Solms, 1974), Butterkäse (Huber and Klostermeyer, 1974), Japanese yeast-ripened cheese (Kaneko and Yoneda, 1974), Gorgonzola (Delformo and Parpani, 1986) and Cottage cheese (Sandine et al, 1972), indicating the universality of this problem, which is a complicated defect affected by many factors. In cheese varieties other than Cottage, bitter flavour development has been associated with proteolysis (Stone and Naff, 1967).

Proteolysis in cheese can be considered synonymous with the degradation of the caseins to peptides and amino acids. Although analysis of the casein sequences reveals that they contain many hydrophobic fragments which are related to the formation of a bitter taste during the hydrolysis of these proteins, identification of bitter peptides isolated from whole casein and from cheese has shown that they originate mostly from $\alpha_{s 1}$ - and $\beta$-casein. It seems reasonable that $\alpha_{\mathrm{s} 1}$ - and $\beta$-caseins with high average hydrophobicities of 1.17 and $1.33 \mathrm{kcal} /$ residue, are potential sources of bitter peptides on hydrolysis (Visser, 1977c). Until now, no reports on the identification of bitter $\mathrm{k}$-casein fragments in cheese have appeared, although Visser et al (1975) have shown that rennet or purified chymosin could generate bitter peptide material from para- $\kappa$-casein.

The $\mathrm{C}$-terminal portion of $\beta$-casein has an extremely bitter taste (Visser et al, 1983b; Shinoda et al, 1986a) and is the principal source of bitter peptides in Gouda cheese (Visser et al, 1983b, c). In Cheddar cheese, $\beta$-casein is highly resistant to proteolysis while $\alpha_{s 1}$-casein is extensively degraded; the main reason for this resistance to proteolysis is the formation of $\beta$-casein polymers that are not readily hydrolysed (Phelan et al, 1973; Creamer, 1975).

Beta-casein was earlier suggested as being the main source of bitterness in dairy products (Sullivan and Jago, 1972). Indeed, strains which produce bitterness in cheese degrade $\beta$-casein at a faster rate than non-bitter strains (Sullivan and Jago, 1972); moreover, processes used for the preparation of partly digested dairy products from whole casein will of necessity give rise to bitter tasting products unless they are capable of reducing the peptide representing the sequence $53-79$ of $\beta$ casein to very small fragments (Clegg et al, 1974). However, the occurrence of bitter defects was observed to be rare in goat and ewe cheeses compared to cow cheeses; cow's milk contains more $\alpha_{\text {s1 }}$-casein, hydrolysates of which are more bitter than those of $\beta$-casein, suggesting that the smaller the amount of $\alpha_{s 1}$-casein, the less bitterness that develops in the cheese (Pélissier and Manchon, 1976).

Bitter peptides produced from casein by the action of rennet (or chymosin), as well 
as proteinases from the cell wall of certain starter bacteria, are degraded by the action of proteolytic enzymes from the cytoplasmic membrane of bacterial cells, either in concert with enzymes from the cytoplasm or without their aid. It is known that salt strongly influences the net formation and degradation of bitter peptides (Visser, 1977b; Visser et al, 1983a). Although many studies report on bitterness in cheese made with various rennet substitutes, the action of exopeptidases from microbial rennets may help in preventing the occurrence of bitterness, and in accelerating the cheese ripening process (Mälkki et al, 1978).

\section{THE ASEPTIC TECHNIQUE}

Before the development of the aseptic vat technique (Mabbitt et al, 1959), the bitter flavour defect had been observed by numerous workers (Moir, 1930; Price, 1936; Raadsveld, 1953), some of whom had been able to show specific causes for it. Strict bacteriological control of the cheese during making was not exercised at that time, and it was generally believed, from the results of cheese-making experiments that starter was the main agent involved in the maturation of Cheddar cheese, while other organisms, in particular lactobacilli, were found to be necessary for the production of Cheddar flavour. However, according to Fryer (1969), the results of such relatively uncontrolled experiments might justifiably be ignored.

Aseptic curds are obtained using a technique of artificial milk acidification (Mabbitt et al, 1955) by the addition of $\delta$-gluconic acid lactone in place of starter (Visser, 1977a; Stadhouders et al, 1983). General information concerning the role of the different ingredients used for cheese manufacture and the general mechanism of pro- tein breakdown during cheese ripening (LeBars et al, 1975; Desmazeaud and Gripon, 1977) have been obtained from these aseptic curds.

Aseptic manufacture of cheese has been performed principally with Cheddar and Gouda cheeses. In the former case, research was mainly directed towards the study of the typical Cheddar flavour (Reiter et al, 1967; McGugan et al, 1968; Reiter and Sharpe, 1971). The aseptic technique of cheese manufacture has conclusively demonstrated the central role of starter lactococci in the development of Cheddar cheese flavour, and that different flavour intensities are related to different starters (Reiter et al, 1967). The contribution of starter lactococci to bitterness production was also studied by Lowrie et al (1974) under controlled bacteriological conditions. It has been concluded, from the study of the rate of acid development during Cheddar cheese manufacture, that the excessive proteolysis which accompanies rapid acidification does not result in the development of bitter flavour (O'Keeffe et al, 1975).

To study aspects of cheese ripening, aseptically made cheeses in which the protein is decomposed during ripening through the separate and combined actions of rennet, starter bacteria and milk protease must be used (Gripon et al, 1975; Visser, 1977a; Visser and de GrootMostert, 1977).

Studies conducted by Visser (1977b, c, d), Visser and de Groot-Mostert (1977) and others in which normal aseptic, aseptic starter-free, aseptic rennet-free, and aseptic rennet and starter-free Gouda cheeses were manufactured, have shown that rennet and bitter starter bacteria were able, separately, to produce bitterness in cheese, although the starter bacteria appeared to do this far more specifically than did rennet by breaking down para-casein in peptides of low molecular weight (MW). 
Cheeses did not develop bitterness when non-bitter starters were used. It was also observed that higher levels of free amino acids accumulated in aseptic rennet-free and normal aseptic cheeses when nonbitter starters were used instead of bitter ones.

Rennet, which is responsible not only for coagulation but also for some aspects of the subsequent ripening (Scott, 1972; Visser, 1977c), has been shown to liberate peptides of high and low MW but only very small amounts of amino acids (AA). In normal cheeses, starter peptidases hydrolyse peptides produced by the action of the rennet leading to the accumulation of $A A$ and low-MW (< $1400 \mathrm{Da})$ peptides. Small amounts of AA and low-MW peptides are also liberated by milk protease.

An experiment conducted by Scott (1972) on Cheddar cheese has indicated that the breakdown of milk constituents was present in the cheese in spite of irradiation destruction of bacteria. Although this treatment produced an intense rancid/ bitter flavour, it has shown that once enzyme systems are present in the curd, living organisms are not necessary for the degradation of milk constituents, as occurs in cheese during ripening.

\section{FACTORS LIKELY TO INFLUENCE BITTER OFF-FLAVOUR DEVELOPMENT IN DAIRY PRODUCTS}

\section{Milk quality}

Dairy products possessing good flavour and shelf-life cannot be consistently produced when made from raw milk of poor organoleptic and bacteriological quality (White et al, 1978).

The feeding of good-quality silage to cows usually results in milk of good quality
(Polansky, 1989), while feeding beet and turnip tops and roots to cows has been found to cause a bitter flavour in the milk (Bassette et al, 1986). When bitter sneezeweed (Helenium amarum) - a warmseason annual widely distributed in the eastern and southern United States - is eaten by cows, it imparts a bitter taste to the milk and renders it unpalatable (Smith, 1989). A single dose of $500 \mathrm{~g}$ or more of green $\mathrm{H}$ amarum to a lactating cow was required to cause appreciable bitterness in milk (Ivie et al, 1975). This off-flavour was found to be very persistent and did not disappear from one milking to the next.

The intensity and persistence of feed and weed flavours in milk are a function of the time interval between feeding and milking, ventilation in the barn, soil fertility, and of the physical condition of the cow. Besides the feeding (Delbeke and Naudts, 1970 ), the composition of milk also varies according to the season (Lawrence and Gilles, 1971), the stage of lactation (Okigbo, 1986), the breed (Richardson and Creamer, 1973), the health of the animal (Sorokina and Karagueuz, 1978) and even the individual (Reiter and Sharpe, 1971).

It is generally suggested that milk with poor rennet coagulation properties should not be used for the manufacture of cheese owing to a reduced yield of cheese with a high moisture content and a very bitter flavour (Okigbo, 1986). Significant quantities of casein cleavage products are to be expected in bulk milk supplies containing substantial amounts of such milk. However, casein cleavage products are also present in normal milk, for example in midlactation milk, but in limited quantities, with time, as more plasminogen is activated and microbial flora increases, higher concentrations of such products accumulate (Visser et al, 1983b).

Milk as produced in the mammary glands is considered to be sterile but mi- 
crobial contamination occurs during passage through the udder. Flavour defects such as bitterness, resulting from this microbial contamination in raw and pasteurised milk, can occur at any stage of production and processing (Bassette et al, 1986).

\section{Psychrotrophic bacteria}

Psychrotrophic bacteria are present in most raw milk supplies and can grow readily at refrigeration temperatures, producing proteolytic and lipolytic enzymes. The results obtained by Gebre-Egziabher et al (1980) and many others (eg, Richardson and Newstead, 1979; Dousset et al, 1988) have shown that all psychrotrophs were hydrolysing casein in raw and processed milk, thus causing bitterness problems.

During cold storage of milk at the farm and at the dairy before processing, the growth of acid-producing bacteria is suppressed while psychrotrophic bacteria, after a certain lag period, start to develop. Several psychrotrophic bacteria (eg, Pseudomonas fluorescens $\mathrm{P}_{26}, \mathrm{~B}_{12}$ and $\mathrm{B}_{52}$ ) especially if they reach a cell population of $10 \% / \mathrm{ml}$, may produce extracellular lipases and proteases that can survive the heat treatments encountered in pasteurisation (73 $\pm 1.0^{\circ} \mathrm{C}$ for $16 \mathrm{~s}$ ) and in the UHT processing of milk $\left(135-150{ }^{\circ} \mathrm{C}\right.$ for $\left.3-10 \mathrm{~s}\right)$, and cause the development of bitter taste (Shipe et al, 1978; Dousset et al, 1988). Both bacterial and native (alkaline) milk proteinases can hydrolyse casein and produce bitter off-flavour in milk and milk products with an extended shelif-life (White and Marshall, 1973b; Richardson and Newstead, 1979; Visser, 1981; Torrie et al, 1983; Dousset et al, 1988). White and Marshall (1973a) have shown that contamination of raw milk having a bacterial count of $<33 / \mathrm{ml}$ inoculated with 160 cells $/ \mathrm{ml}$ of
Pseudomonas fluorescens $\mathrm{P}_{26}$ produced significant proteolysis and bitter off-flavour in UHT pasteurised milk stored at $4.4^{\circ} \mathrm{C}$ for up to 20 days. However, even in the absence of post-pasteurisation contaminants, off-flavours may be encountered after pasteurisation of raw milk containing large populations of psychrotrophs due to: 1) end-products of microbial metabolism; 2) constituents of large numbers of heatinactivated and lysed bacterial cells; 3) heat-stable microbial enzymes; 4) presence and growth of thermoduric psychrotrophs (Patel and Blankenagel, 1972).

A lipase and several esterases occur naturally in milk, the lipase attacks the milk triglycerides, releasing free fatty acids and forming mono- and diglycerides which are responsible for the bitter flavour that occasionally accompanies lipolysis (Lebedev and Umanskit, 1981; Choisy et al, 1984; Bassette et al, 1986). Dibutyrin is the bitter flavour principle in homogenised raw milk. Since the growth of lactic streptococci is depressed in lipolysed milk, it is possible that slow lipolysis which occurs in milk held in bulk tanks could produce enough acids to slightly inhibit the growth of lactic cultures and, as a result, the flavour and odour of milk may be altered and the surface and interfacial properties modified (Jensen, 1964). In order to help the milk to recover its physico-chemical and biochemical properties, Desmazeaud (1983) has proposed the storage of good bacterial quality milk for $12-15 \mathrm{~h}$ at $10^{\circ} \mathrm{C}$ in the presence of $0.1-0.2 \%$ of starter.

McKellar (1981) was the first to report an attempt to associate bitterness development in milk with proteolysis measurement. $\mathrm{He}$ found that proteolysis ranging from $0.289-0.554$ and from $0.499-0.746 \mu \mathrm{mol}$ of trichloroacetic acid-soluble free amino groups $/ \mathrm{ml}$ for UHT and pasteurised milk, respectively, was necessary for significant off-flavour development. 
Bitter flavour which frequently developed under commercial handling of Cottage cheese was associated with increases in soluble nitrogen and psychrophilic bacteria. Also, much of the White cheese offered in Egyptian local markets is bitter and highly acidic due to raw milk heavily contaminated with lactobacilli (AboElnaga, 1974). Similarly, Greek Teleme cheeses made with raw milk stored for 5 days were unacceptable for body and texture and were rejected because of rancidity, unclean flavour and bitterness due to the presence of psychrotrophic bacteria (Kalogridou-Vassiliadou and Alichanidis, 1984). Other workers (Chapman et al, 1976; Law et al, 1976; Hicks et al, 1986) have found similar off-flavours in Cheddar cheese made from cold-stored milk.

\section{Treatment and $\mathrm{pH}$ of the cheese milk}

As early as 1930 , Moir observed that cheese made from pasteurised milk develops a bitter flavour, a defect more pronounced for milk flash-pasteurised at $85^{\circ} \mathrm{C}$ than at $74^{\circ} \mathrm{C}(20-30 \mathrm{~s})$. As mentioned by Stadhouders (1962), cheesemaking from over-pasteurised milk is still not allowed in the Netherlands; indeed, by this process more rennet is retained and the cheese has a greater chance of becoming bitter. This was confirmed for Gou$\mathrm{da}$ and Cheddar cheeses produced from milk of low $\mathrm{pH}$ (pH 6.25) (Stadhouders and Hup, 1975). The pattern of proteolysis is altered during maturation; consequently, there is more intensive breakdown of the $\alpha_{s 1}$-casein and increased bitterness in the Cheddar cheese (Creamer et al, 1985).

The lowering of the initial $\mathrm{pH}$ of cheese milk happens when: a), the milk is of inferior quality and acid formation has taken place (Okigbo et al, 1985); b), the milk is pre-ripened with starter; or c), a large amount of starter has been used. A solution to this problem may be achieved by reduction of rennet levels (Banks, 1988) and manufacture of Cheddar cheese according to the method of Banks et al (1987), which includes incorporation of denatured whey protein into the curd. However, the development of high quality Cheddar cheese flavour was impaired by this technique.

\section{Bacteriophage proliferation in the cheese vat}

The presence of antibiotics or bacteriophages seriously inhibits the starter activity and prevents or reduces the development of bitterness (Stadhouders, 1974).

Bacteriophage contamination during making, at levels which restricted starter growth in the final stages of manufacture without markedly affecting acid production, had a striking effect on cheese flavour, especially the intensity of bitterness (Lowrie et al, 1972), and was responsible for longer cheese-making times on subsequent days (Lawrence and Gilles, 1973; Lowrie, 1977). The cheeses manufactured under controlled bacteriological conditions both with the normally bitter strain Lactococcus lactis subsp lactis $\mathrm{ML}_{8}$ or the slow acid-producing strain Lactococcus lactis subsp cremoris $\mathrm{AM}_{2}$ at a low cooking temperature developed an intense bitter flavour; however, this defect was almost entirely eliminated from cheese made in the presence of bacteriophage (Lowrie et al, 1974). Since significant bacteriophage contamination may occur without apparent effect on acid production during cheesemaking, instances of such bacteriophage infection must be widespread in commercial cheese-making operations, even when so-called "phage-tolerant" or "phageresistant" starters are used (Lowrie, 1977). 
Many years ago, cheese of good flavour, as well as complete control over bacteriophage could be obtained by rotation of carefully selected pairs of starters (Lawrence and Gilles, 1973; Gavron et al, 1982). The information that bacteriophage does not replicate in non-growing cells which still retain the capacity to ferment lactose to lactic acid would appear, as suggested by Hillier et al (1975), to form a basis for the control of phage proliferation in cheese factories.

\section{Fat content}

Cheddar cheese made from pasteurised milk with a reduced fat content $(1.5 \pm$ $0.1 \%$ ) has been found to develop an increasingly acid and bitter flavour (Deane and Dolan, 1973). On the other hand, this off-flavour defect was also observed in Italian cheeses such as Crescenza, Gorgonzola and Robiola when they were manufactured from milk with a high fat content (Delformo and Parpani, 1986).

Hydrolytic cleavage of fatty acids from milk fat by the lipase, which is secreted by microbial contaminants in milk, can produce bitter off-flavour (Bassette et al, 1986), as discussed before.

\section{Choice of starter}

As observed by Lawrence and Gilles (1969), the most important role in bitterness is played by the starter. Tests by Hansen et al (1933) indicated that addition of more than $4 \%$ of a culture of Streptococcus paracitrovorus to raw or pasteurised cheese milk resulted in cheese with a bitter flavour and open texture. This was also true of Steptococcus citrovorus when an inoculum of $1-10 \%$ was used, regardless of the kind of milk (raw or pasteurised). Addition of 0.1 to $0.5 \%$ of a culture of Streptococcus liquefaciens to the regular starter resulted in cheese with a flavour so bitter that it became unpalatable (Deane, 1951). Similar results were obtained by Yates et al (1955), who made Cheddar cheese with cultures of Streptococcus faecalis var liquefaciens previously isolated from raw milk cheese or whey. Marked proteolysis and bitterness resulted in cheese prepared with pasteurised cheese milk, added Streptococcus liquefaciens and a lactic starter (Tittsler et al, 1948). Outgrowth and survival characteristics of starter bacteria during cheese ripening have been implicated in the development of Cheddar cheese flavour as well as of bitter flavour (Perry and McGillivray, 1964; Reiter et al, 1967; Martley and Lawrence, 1972; Lowrie et al, 1974).

For many years starter lactococci have been classified as bitter or non-bitter according to whether or not they consistently produce bitterness in Cheddar cheese (Emmons et al, 1962a; Lawrence and Gilles, 1969). Two simple methods for detecting bitter strains have been proposed by Klimovsky et al (1970). The first method consists of evaluating the flavour of curds of skim-milk and of skim-chalk-milk made with rennet in concentration of $0.7 \mathrm{~g} / \mathrm{l}$ of milk following incubation for $24 \mathrm{~h}$ and 7 days at $26^{\circ} \mathrm{C}$ with the strains being tested. Selected strains were used in the manufacture of Kostroma, a Russian cheese. There was a perfect correlation between bitterness in the cheese and bitterness in the 7-day test. The second method is based on the ability of lactic acid bacteria to form peptides rapidly and to produce glutamate slowly in milk, following addition of rennet, knowing that the most bitter strains consistently produce less glutamate than non-bitter strains, independently of the milk or rennet used. Hillier et al (1975) 
have shown that the estimation of bacterial growth in milk containing $1 \%$ yeast extract, at $\mathrm{pH} 6.3$ and $37.5^{\circ} \mathrm{C}$, by a rapid absorbance method, provides a simple means of identifying strains likely to produce high or low cell populations in the curd and hence, either a bitter or non-bitter cheese. Certain strains of $P$ roqueforti and $P$ caseicolum have been shown to be responsible for the development of bitterness in Camembert cheese (Adda et al, 1982). According to the findings of different workers (Martley and Lawrence, 1972; Sullivan and Jago, 1972; Choisy et al, 1978) a fast method is proposed, based on the determination of the starter growth rate, proteolysis and proline-iminopeptidase activity, to characterise lactococcus strains for their capacity, if any, to develop bitterness in cheese.

Bitter and non-bitter strains are supposed to differ only in their resistance to the cooking temperature applied in Cheddar cheese production $\left(\approx 38^{\circ} \mathrm{C}\right)$. At this cheese cooking temperature, since the growth of the non-bitter strains is repressed while that of the bitter strains is not, a high final total population of starter organisms in the curd, irrespective of strain, has been thus shown to be the major factor producing bitterness in cheese (Lowrie et al, 1972). The viability of starter cultures in milk incubated at different temperatures has been used (Sullivan et al, 1974) to indicate the potential of individual strains to produce bitter or non-bitter cheese at specific cooking temperatures. It has been observed (Phillips, 1935) that for 3 different cultures of Lactococcus lactis subsp lactis, when the $\mathrm{pH}$ value of the cheese was $\leq 5.00$ at 4 days, bitter flavour subsequently developed. As suggested by Harris and Hammer (1940), if a Micrococcus is to be employed in making Cheddar cheese from pasteurised milk, it should be selected on a strain rather than on a spe- cies basis because of the differences between cultures apparently belonging to the same species. As reported by Klimovsky et al (1970), Lactococcus lactis subsp lactis and Lactococcus lactis subsp cremoris strains may give rise to bitterness in Cheddar cheese and also in Dutch-type cheeses. Martley and Lawrence (1972) have also come to the conclusion that it is unwise to regard $M L_{1}$, a strain of Lactococcus cremoris, as a typical non-bitter starter because this strain gives slightly bitter and other characteristic off-flavours, variously described as "burnt" or "malty". Similarly, Lawrence et al (1972) stated that the strain of starter used appeared to be the only factor controlling the acceptability of Cheddar cheese and the development of offflavours such as bitterness when normal commercial cheese-making conditions were used. Their finding is not in full agreement with the conclusions of Reiter and Sharpe (1971) from trials with cheese made under carefully controlled conditions in an aseptic vat, that the chemical composition of the milk (which may be influenced by the feed of the cows and the effect of the native milk enzymes, ie lipases and proteases) and the bacteriological quality of the cheese milk may also influence the development of cheese flavour.

The culture characteristics play a more decisive role in bitter flavour production than the type of milk-clotting enzyme (Nelson, 1974). Cheeses made with "slower" starter strains $\left(M_{1}, E_{8}, T R, R_{1}, U_{3}\right.$, $\mathrm{SK}_{11}, \mathrm{AM}_{1}$ and $\mathrm{AM}_{2}$ of Lactococcus lactis subsp cremoris (Exterkate, 1976)) have been found to exhibit good flavour, quite free from bitterness, while those made with "faster" starter strains $\left(\mathrm{HP}, \mathrm{C}_{13}, \mathrm{KH}, \mathrm{FD}_{27}\right.$ and $\mathrm{Wg}_{2}$ of Lactococcus lactis subsp cremoris (Exterkate, 1976)) exhibited bitterness. The starter strains HP and $\mathrm{Wg}_{2}$ were found to be capable of producing bitter cheeses on their own, without any interaction with 
rennet (Visser, 1977b). When used as supplemental starters, strains of Streptococcus faecalis were found unsuitable for Cheddar cheese manufacture because they produced more defective flavours than did their controls. However, 2 strains of Streptococcus durans (15-20 and 9-20) could be considered for supplemental use as commercial starters because they significantly and consistently produced cheeses with fewer defects than their controls, which were manufactured only with lactococci (Jensen et al, 1975). As observed by Lawrence et al (1976), Lactococcus lactis subsp cremoris strains are less likely than Lactococcus lactis subsp lactis strains to give fruity and bitter defects in Cheddar cheese. The central role of starter bacteria in the ripening of Gouda cheese has been established by Kleter (1976), who found that it was possible to make Gouda cheese with a normal ripening process and normal organoleptic properties when no bacterial enzymes other than those from a proper starter Lactococcus lactis subsp cremoris were active in the cheese. Lactococcus lactis subsp lactis $\mathrm{C}_{2}$ has the potential to produce bitter cheese based on its growth in milk at the normal cooking temperatures for Cheddar (Sullivan et al, 1974; McKay and Baldwin, 1978). Improvement of Lactococcus lactis subsp lactis $\mathrm{C}_{2}$ as a potential Cheddar cheese starter, by genetic manipulation, reduced the proteolytic activity of the stabilised transductants as compared to the parent. This resulted in a reduction in the formation of bitter flavour in Cheddar cheese (Kempler et al, 1979).

Lactic starters prepared from non-bitter strains such as Lactococcus lactis subsp lactis INIA 12, may be employed to minimize the risk of bitterness in cheese varieties where fast acid production is not essential for the manufacturing process, ie Spanish Burgos cheese manufactured from pasteurised milk, but without inoculation with lactic starters (Chavarri et al,
1988). However, as reported by Nuñez et al (1982) there is no specific commercial starter for the manufacture of Manchego cheese in Spain, and bitter flavour defects due to the use of imported starters have been frequently observed.

Lowrie et al (1972) have concluded that culture strains which produce little or no bitterness and good cheese flavour exhibit one or more of the following characteristics: 1), a low rate of cell division at normal cheese cooking temperatures; 2 ), poor survival in cheese during curing; 3 ), low proteolytic activity; 4), high acid phosphatase activity (Dinesen, 1974; Nelson, 1974).

\section{Behaviour of bitter and non-bitter strains}

Lawrence and Gilles (1969) observed that cheese was seldom bitter when non-bitter strains were used as starter, regardless of the amount of rennet, salt or moisture present, or the rate of acid production in the curd, or the final $\mathrm{pH}$ of the cheese. However, when bitter strains were used, the cheese was invariably bitter except when the salt-in-moisture levels and the $\mathrm{pH}$ of the cheese were relatively high. They also found (Lawrence and Gilles, 1971) that the bitterness of cheese manufactured with the bitter strains was directly proportional to the amount of rennet used. This was in contrast to cheese manufactured with the non-bitter strains, since a 2or 3 -fold increase in the amount of rennet used did not produce a bitter cheese (Jago, 1974).

As mentioned by Exterkate and Stadhouders (1971), bitter and non-bitter strains of lactococci differ in their growth characteristics: bitter strains grow rapidly under normal cheese-making conditions and reach high populations in the cheese curd prior to salting; on the other hand, the multiplication of non-bitter strains is inhibit- 
ed at the normal cooking temperature in cheese-making. According to their results, all strains must therefore be potentially capable of contributing directly to the formation of bitter-flavoured components in cheese.

If the starter population density in the cheese at salting is allowed to become too high, however, flavour defects such as bitterness or fruitiness are produced and detract from or mask cheese flavour (Lawrence et al, 1976). The role of starter may therefore be merely to provide a suitable environment which allows the elaboration of cheese flavour (Lowrie et al, 1974).

As reported by Dunn and Lindsay (1985), even if many strains of lactococci $\left(e g, \mathrm{ML}_{8}\right.$ ) produce bitter peptides in more aged cheeses, they are preferred to nonbitter strains because of their efficiency in the cheese-making process. Indeed, these latter strains tend to be sensitive to salt and exhibit poor survival in cheese. It is then advisable, in order to avoid the development of off-flavours and bitterness, to select the bacterial population of a starter on the basis of its proteolytic activity and its rate of lactic acid production over the entire range of temperature and $\mathrm{pH}$ occurring during manufacture and maturation of cheese (Emmons et al, 1962a).

\section{Bitterness in cheese and degradation of bitter peptides}

From their experiments, Emmons et al (1960a, b) concluded that bitterness in Cheddar cheese is closely associated with the strain of starter culture. Their results suggested that bitterness was due to a deficiency, in the strains used, of proteolytic enzymes capable of hydrolysing bitter primary breakdown products of the cheese protein. According to the nitrogen content of Cheddar cheese samples (Emmons et al, 1962a), strains that produced bitter cheese hydrolysed bitter-tasting peptides less extensively than strains that produced non-bitter cheese. Jago (1962) came to a similar conclusion, ie that the differences between bitter and non-bitter strains were due to the inability of bitter strains to hydrolyse the bitter peptides produced by rennet. It was suggested that bitterness may result from the formation of pyrrolidone carboxylic acid (PCA) at the N-terminal end of a hydrophobic peptide derived from casein during proteolysis. Later, Sullivan and Jago (1970a, b) claimed that the possession of a pyrrolidone carboxylyl peptidase by non-bitter, but not by bitter starters, was the critical difference between strains in their ability to degrade bitter peptides. This enzyme specifically hydrolyses the peptide bond joining PCA residues to the remainder of peptides and proteins. This was further correlated by the detailed investigation of Exterkate and Stadhouders (1971) who showed that the enzyme activity was not only present, but was higher, in cell extracts from bitter strains than from non-bitter strains.

When the amount of bitter peptides present in bitter as well as in non-bitter cheeses exceeds the threshold value for bitter taste perception, the cheese is rated bitter (Visser et al, 1983b). Two reasons why the concentration of bitter peptides may never exceed the threshold at which bitterness can be detected in cheese made with non-bitter strains were reported by Lawrence et al (1972): a), non-bitter starters would be expected to degrade high MW peptides at a slower rate since they exhibit less proteolytic activity in cheese than bitter starters (Martley and Lawrence, 1972); and b), non-bitter strains may have a peptidase activity greater than that of bitter strains. The conclusion of Gordon and Speck (1965) that a bitter strain was more proteolytic than a non-bitter one in milk cul- 
ture was later asserted to be a non-general feature of all bitter and non-bitter starter strains (Martley and Lawrence, 1972). All the bitter strains are capable of producing bitter peptides from casein by the action of their specific cell wall proteinase(s) (Mills and Thomas, 1980; Exterkate, 1983). However, slow variants of these strains ie, those which give no off-flavours under normal conditions (Lawrence and Pearce, 1968) have lost this ability. Whole cells of Lactococcus lactis subsp cremoris HP can produce bitter peptides only from whole and $\beta$-caseins and degrade only chymosingenerated bitter peptides from $\alpha_{\mathrm{s} 1^{-}}$and (para)-к-casein (Visser et al, 1983c).

\section{Reduction of bitterness in cheese}

As shown by Sullivan et al (1973), the power of each strain to remove the bitter taste is directly related to its ability to hydrolyse the bitter peptides to amino acids. A strain of Pseudomonas fluorescens, VTTE 8.7 , originally isolated from soil and able to produce a complex of endo- and exopeptidases, has been found to prevent, in the presence of a microbial rennet, the formation of bitter taste in Edam cheese (Mälkki et al, 1976, 1978). Indeed, this strain produces proteinases and peptidases able to convert, under laboratory conditions in culture flasks, $60-90 \%$ of the milk proteins to free amino acids; therefore, the breakdown of bitter compounds will allow a modification of taste properties (Mälkki et al, 1979). Knowing that bitter starters lack the protease enzyme able to degrade bitter peptides, Sood and Kosikowski (1979) suggested that addition, at low levels, of microbial proteases such as fungal protease 31000 from Aspergillus oryzae, microbial protease P-53 of Bacillus subtilis, or lipase-MY from Candida cylindracea, to the bitter starter may lead to cheeses free of bitterness. According to Lawrence et al
(1976), the use of cultures containing slowcoagulating variants (Stadhouders, 1974) for Gouda cheese, and the use of strains that cannot grow at $38{ }^{\circ} \mathrm{C}$ (Lowrie and Lawrence, 1972; Martley and Lawrence, 1972; Jago, 1974) for Cheddar cheese would seem to be logical approaches to the prevention of bitterness. A reduction in the maximum starter population or the deliberate infection of the starter with homologous phage was shown by Martley (1975b) to result in a marked reduction or elimination of bitterness and in a great improvement in the overall flavour acceptability of Camembert cheese. A better flavour, with a lower incidence of bitterness was also noticed for Gouda cheese manufactured with thawed single strain lactococci concentrates inoculated directly to the cheese milk (Martens, 1974).

The starter culture can be altered by inclusion of a high level of mutant strains (Prt) with a substantial deficiency in surface-associated proteinase and with the same peptidase activities as the parent cell (Kamaly and Marth, 1988). Because bitter flavours are related to proteinase positive $\left(\mathrm{Prt}^{+}\right)$cell activity, use of cultures containing a high proportion of proteinase negative $(P r)$ cells may represent a logical approach for reducing bitterness development in cheese (Mills and Thomas, 1980, 1982; Richardson et al, 1983). A non-bitter Cheddar cheese has thus been produced using a high level $(45-75 \%$ Prt cells), of variants of Lactococcus lactis subsp lactis $\left(\mathrm{C}_{2}\right)$ Lac-Prt used to increase the normal starter population of experimental cheeses without increasing the rate of acid production during the manufacturing process. The absence of bitterness in the final product has then indicated that the intracellular peptidase system of the added mutant strain was efficient in degrading bitter peptides (Grieve and Dulley, 1983). A decrease in bitterness in Cheddar was 
also obtained for cheese manufactured with starters containing $\mathrm{Prt}$ variants of Lactococcus lactis subsp cremoris and Lactococcus lactis subsp lactis (Monnet et al, 1986). Bitter cheese will no longer be produced when an originally bitter strain in which the "slow" variants, or those who have lost the ability of forming bitter peptides from casein, have grown to a large proportion of the culture (Mills and Thomas, 1980; Stadhouders et al, 1983) is used as a starter. Exterkate (1976) suggested that the presence of proteolytic activity $P_{I I}$ was correlated with bitter peptide production; non-bitter peptide producers such as Lactococcus lactis subsp cremoris strain $M L_{1}$ produced only $P_{1}$ and $P_{I I I}$. It was later demonstrated by Hugenholtz et al (1984) that strain $\mathrm{ML}_{1}$ contains the same proteolytic system as the bitter peptide producing strains $\mathrm{Wg}_{2}, \mathrm{HP}$ and $\mathrm{C}_{13}$. As this strain excretes most of its proteases into the surrounding medium, the proteases do not remain in the curd and do not contribute to bitter peptide formation during cheese ripening.

\section{Starter-pairing}

It is now recognised that the use of certain starters results in bitterness in cheese and that pairing of "bitter" starters with "nonbitter" starters markedly reduces bitterness in Cheddar (Lawrence and Pearce, 1968; Creamer et al, 1970) and Gouda (Visser, 1977b) cheesemaking.

Emmons et al (1961, 1962a, b) studied bitterness in pasteurised milk cheese as influenced by different combinations and proportions of paired strains of Lactococcus lactis subsp cremoris in the starter. They found that the level of bitterness decreased as the proportion of non-bitter strains in the starter culture increased. Non-bitter cheese was made by combining a bitter and a non-bitter strain in suitable proportions as starter in the vat. In a similar way, Creamer et al (1970) reported the undesirability of using "fast" single strain starters ( $\mathrm{HP}, \mathrm{P}_{2}, \mathrm{ML}_{8}$ ), unless these are paired with a "slow" starter $\left(\mathrm{AM}_{2}\right)$ in order to reduce the bitterness to an acceptable level; however, the bitterness of the starter cannot be suppressed entirely by this pairing. The very significant decrease in bitterness observed when the mixed starter was used can be totally explained as a dilution effect of the bitter starter by the non-bitter starter. Experiments have clearly shown that the proteolytic activity of bitter strains is different from that of non-bitter strains (Stadhouders, 1974), and that the interaction between one strain and another may be important (Reiter and Sharpe, 1971). The suitable pairing of such strains can thus contribute to considerably reduce bitter flavour in cheese.

\section{Factors implicated in starter activity and in starter failure}

The temperature of storage has been found to be critical for starters. They remain active for only a few weeks at $-20^{\circ} \mathrm{C}$, but lose no activity at $-40^{\circ} \mathrm{C}$ when stored for 6-8 months, a period which would be long enough for successful commercial use. Freezing in liquid $\mathrm{N}_{2}\left(-196^{\circ} \mathrm{C}\right)$ is now the most common practice in dairying countries. Even if storage of starter concentrate at $-40^{\circ} \mathrm{C}$ results in a slightly lower level of cell survival compared to storage at $196^{\circ} \mathrm{C}$, the difference is unlikely to be significant when concentrates are used to inoculate mother cultures and bulk starter vessels, or even for direct vat inoculation in the case of Dutch-type cheeses (Lawrence et al, 1976).

The most important extrinsic factors implicated in starter failure are antibiotics and 
bacteriophage attack. Since starter bacteria are sensitive to very low concentrations of antibiotic residues, milk containing antibiotics should not be accepted or used for the manufacture of cheese. However, Gavron et al (1982) were able to manufacture non-bitter Gouda cheese in the presence of antibiotics, and bitter cheese in the absence of antibiotics by using group $\mathrm{N}$ streptococcus strains which had previously been made resistant to penicillin and bacteriophage, and which were stable with regard to both lactose metabolism and proteinase activity.

An alternative method of slow and continuous acidification in cheese-making by substituting $\delta$-gluconic acid lactone (GAL) for the starter organism was developed by Mabbitt et al (1955). This technique was also used (O'Keeffe et al, 1975) in Cheddar cheese manufacture to simulate the $\mathrm{pH}$ development pattern of starter cheese. These latter workers observed a very marked increase in proteolysis caused by a rapid early acid development in the cheese, and concluded that bitterness was not obviously connected with the level of proteolysis; in fact the excessive proteolysis which accompanies rapid acidification does not result in the development of bitter flavour. The contribution of rennet (or rennet substitutes) to the ripening process may be assessed by the use of aseptic cheeses in which acidulation is simulated by this technique (Visser, 1977a; Stadhouders et al, 1983).

Cheddar cheese manufactured under controlled bacteriological conditions using GAL in place of starter was sharp or bitter (Perry and McGillivray, 1964; Reiter et al, 1967), and Gouda cheese did not develop any cheese taste or flavour at all. Howev$\mathrm{er}$, after some months of ripening the latter became bitter (Kleter, 1976).

\section{Amount of rennet and starter added to the cheese milk}

According to Stadhouders (1962), 3 main factors control the concentration of rennet in cheese: 1), the quantity of rennet used in cheese-making; 2), the manner in which the curd is washed and dried (with short drying and washing times, more rennet remains in the cheese); 3 ), the $\mathrm{pH}$ of the milk and curd during cheese-making. When the $\mathrm{pH}$ of the curd is much below the normal $\mathrm{pH}$ of milk ( $\mathrm{pH} 6.5-6.6)$, the casein retains more rennet, which is then found in larger quantity in the cheese.

The rennet concentration used in Cheddar cheese-making has an important influence on the development of bitterness, especially when temperature-insensitive strains are used (Scott, 1972; Mills and Thomas, 1980). Lawrence et al (1972) have shown that with these strains $\left(A M_{1}\right.$, $\mathrm{AM}_{2}$ ), increased rennet levels gave more bitter cheese. As found by Lawrence and Gilles (1971), bitterness scores were directly proportional to the level of rennet used with the fast lactococci starters (HP, $M L_{8}, Z_{8}, B A_{1}, E_{8}$ and $M L_{1}$ ). However, no increase in bitterness was observed with 2- to 3-fold increases in rennet used with the slow streptococci starters $\left(A_{1}, A M_{2}\right.$ and $U_{3}$ ).

Bitterness in Mozzarella cheese made by direct acidification (Keller et al, 1974) and in a Japanese yeast-ripened cheese (Kaneko and Yoneda, 1974) may be avoided by reducing the amount of rennet.

Since the relative clotting power of rennet is not constant during the normal dairying season (Lawrence and Gilles, 1969, 1971), the level of rennet used throughout the season could be varied according to its clotting power. This would save money by 
reducing the amount of rennet used, and would also lower the incidence of bitterness in Cheddar cheese when certain "fast" starters are used. Furthermore, it is still possible to reduce the level of rennet normally used (70-85 g per $450 \mathrm{~kg}$ of milk) when the setting temperature is raised by $0.63-1.26{ }^{\circ} \mathrm{C}$.

The rennet retention is linearly related to the amount of rennet added to the milk (Visser, 1977a). Retention is greatly increased with decreasing milk $\mathrm{pH}$ and with greater starter activity (Stadhouders and Hup, 1975; Lawrence et al, 1984). A study by Vassal and Gripon (1984) on Camembert-type soft cheeses, made with Lactococcus lactis subsp cremoris and Penicillium caseicolum as surface flora, has led them to conclude that the $\mathrm{pH}$ of the milk at renneting modified only slightly the quantity of rennet retained in the curd, whereas the quantity of rennet had a much greater influence. In fact the amount of retained rennet varied almost in a linear manner but did not affect the development of bitterness.

The significance of both the starter strain and type of rennet used in the development of the bitter flavour defect in the manufacture of Cheddar cheese was shown by Lawrence et al (1972): 1), the calf rennet concentration determined both the acceptability and the intensity of bitterness when the "faster" strains of starter were used; 2), at any given calf rennet concentration the strain of starter used determined the flavour and acceptability of the resulting cheese.

Research in New Zealand has clearly established that if starter and non-starter growth is controlled so as not to reach levels that produce off-flavours and if as little rennet as possible is used, the flavour which develops in Cheddar cheese is likely to be acceptable to most consumers. It is probable that a similar situation exists in all cheese varieties (Lawrence et al, 1983). The rennet activity depends on its concentration in the cheese (Stadhouders, 1974) and to a great extent on the salt content (Stadhouders, 1962; Fox and Walley, 1971). There is more opportunity for the chymosin to be active in the interior of cheeses which are brined or rubbed with salt than in cheeses of which the curd is mixed with salt before pressing.

Based on the results obtained with aseptically-made Gouda cheeses, Visser (1977b) concluded that rennet alone has the potency to produce bitter peptides and, if retained in high concentrations, to make the cheese very bitter. It was also observed that the contribution of rennet to the development of bitterness in Cheddar cheese is not as important as in Gouda cheese (Stadhouders and Hup, 1975; Visser, 1977b).

Milk ultra-filtration (UF) can be used in cheese-making to produce a retentate with total solids at a suitable level; the retentate is thus a concentrate of protein and fat, and the permeate is a solution of lactose and minerals (Mortensen, 1984). Creamer et al (1987) manufactured Cheddar cheese from milk concentrated 5 -fold by UF, and observed that despite the relatively high residual rennet concentration in the product (up to $33 \mathrm{RU} / 1000 \mathrm{~g}$ cheese), bitterness was not detected. Rennet activity appears to be somewhat inhibited in UF Cheddar cheese. Such inhibition is likely to be due to whey proteins (Creamer et al, 1987). Moreover, incorporation of whey proteins in the UF cheese-making process also has an effect on the characteristics and yield of product and then limits the extension of the range of UF cheeses on the market (Lelievre and Lawrence, 1988).

Mistry and Kosikowski (1986a, b) have shown that starter concentration is important when retentates are used as bulk starters; beyong $1 \%$ starter, higher yield in- 
creases were possible, but bitterness developed in the cheese stored for 4 months at $10^{\circ} \mathrm{C}$. In the manufacture of traditional Cheddar, the rates of acid development and moisture expulsion are critical. Therefore, the amount of normal starter culture added to the cheese milk cannot be greatly increased without affecting the quality of the final product. Lowrie et al (1974) have shown that a high viable starter population in curd leads to the development of bitterness. However, Grieve and Dulley (1983) have demonstrated that high starter levels do not necessarily produce bitterness and, in their experiments, have even produced Cheddar cheese with superior flavour scores. In order to increase the normal starter population of experimental cheese without increasing the rate of acid production during the manufacturing process, they used frozen mutant concentrates of a Lactococcus lactis subsp lactis $\mathrm{C}_{2}$ Lac $^{-}$ $\mathrm{Prt}$.

\section{Calf-rennet substitutes}

Supply shortages and variations in the quality of rennet from young calves spurred efforts to discover suitable rennet substitutes (Dinesen, 1974). Since most of the proteinases will coagulate milk under suitable conditions, many proteolytic enzyme preparations of animal, plant and microbial origin have been assessed as replacements for calf rennet in the manufacture of many standard types of cheese. Very substantial numbers of people in the world are opposed to the use of certain animal secretions in cheese production on grounds of religion, morality, or diet. All these factors have contributed to the worldwide search for animal rennet substitutes of microbial or plant origin. Enzymes from the fig (ficin), pineapple (bromelain), papaya (papain), fungi (Endothia parasitica, and Mucor miehei, Mucor pusillus) or bacteria (Bacillus subtilis, B cereus) have been and are used as coagulants in the cheese process. Unfortunately, many of the rennet substitutes have undesirable side-effects, eg, bitter flavour. Any substitute for calf rennet must not only coagulate milk, but must have low proteolytic activity and produce cheese with acceptable flavour and rheological characteristics (Quarne et al, 1968; Edwards and Kosikowski, 1970; Sardinas, 1972; Scott, 1972; Hofi et al, 1976; Rao et al, 1979).

Calf rennet, which contains chymosin (rennin) as the main enzyme component, is well known as the best milk coagulant. While in the Netherlands no type of rennet other than calf rennet is allowed for cheese-making without special exemption (Visser, 1981), the use of substitutes from animal, plant or microbial origin has become a more general practice in several countries.

\section{Animal origin}

Cheddar cheese made using only porcine pepsin tends to have a bitter flavour when fully ripe (Scott, 1972). However, the use of porcine pepsin in rennet mixtures may be of advantage because it contributes strongly to clotting, while it is largely inactivated under the subsequent processing conditions. Chymosin is more specific than pepsin, and therefore exhibits a more limited proteolytic behaviour (Visser, 1981). Hence, in admixture with rennet, porcine pepsin has a limited proteolytic action during cheese ripening; this avoids the development of flavour defects such as bitter taste.

In a small number of studies, use of commercial and pure chicken pepsin preparations in the manufacture of Cheddar cheese did not affect the cheese-making 
conditions, yield or cheese composition. However, the final product underwent faster proteolysis, more intense flavour, offflavours and bitterness and was softer than cheese made with calf rennet (Stanley et al, 1980; Green et al, 1984).

\section{Plant origin}

As early as 1956, Windlan and Kosikowski used papain for Cheddar cheese manufacture. Unfortunately, bitterness was severe enough to make the cheese unfit for consumption.

A vegetable rennet extracted from Withania coagulans berries has been used to prepare Cheddar cheese from cow and buffalo milks. The former cheese was slightly bitter while that made from buffalo milk was inferior in quality and had a bitter flavour (Singh et al, 1973).

A coagulant obtained from the flowers of Cynara cardunculus $\mathrm{L}$ and used traditionally in Portugal for the manufacture of ewe cheese of Serra and Serpa types, has been assessed in the manufacture of Camembert and Gruyère cheeses. Unfortunately, these cheeses developed very pronounced bitterness (Barbosa et al, 1976).

\section{Microbial origin}

Microorganisms represent a large, inviting reservoir of potential animal rennet substitutes. However, the majority of microbial rennets are much too proteolytic for cheese-making. Replacement of chymosin by microbial rennets influences cheese ripening: proteolysis of $\alpha_{s 1^{-}}$and $\beta$-caseins is increased and retarded, respectively, as observed by Christensen et al (1989) who suspected the type of rennet used in the cheese manufacture to have an effect on bitter flavour development in the final prod- uct. The bitter taste, often associated with increased proteolysis, may result from a different pattern of casein breakdown and an increased breakdown of whey proteins (Schulz and Thomasow, 1970).

The criteria that a microbial rennet preparation must meet in order to substitute satisfactorily for animal rennet are the following: 1), the preparation must effectively coagulate milk without excessively hydrolysing the resulting curd during or at maturation; 2), it must be non-toxic and devoid of antibiotic activity, as well as free of pathogens; 3), preferably, it should be readily water-soluble and possess acceptable colour and odour; 4), it should exhibit reasonable shelf-life (Sardinas, 1972).

Without giving any details, Windlan and Kosikowski (1956) reported that when rennet-like enzymes from microbial sources were used at optimum concentration, smooth curds resulted. Bitter flavours in either curd or Cheddar cheese were relatively insignificant.

Edam, Gouda and Cheddar type cheeses made with microbial rennets obtained from Mucor pusillus Lindt and Bacillus polymyxa were bitter. Kikuchi and Toyoda (1970) attributed this off-flavour to the inherent characteristic of the microbial milk clotting enzymes and concluded that microbial rennets could replace the conventional calf rennet in cheese-making if aspects of manufacture were modified to suit microbial rennets.

Lawrence et al (1972) found that both Rennilase and Meito microbial rennets, obtained from Mucor miehei and Mucor pusillus var Lindt, respectively, produced considerably less bitterness in Cheddar cheese manufactured with a bitter strain (Lactococcus lactis subsp cremoris strain HP) than did calf rennet. However, not all microbial rennets were alike in this respect, since a rennet obtained from En- 
dothia parasitica produced bitter cheese even with a non-bitter starter (Lactococcus lactis subsp cremoris strain $\left.\mathrm{AM}_{2}\right)$. On the other hand, a "somewhat bitter" flavour appeared more frequently in Gouda made with the microbial rennets, Rennilase and Fromase, than with calf rennet (Martens, 1973).

Microbial rennet substitutes such as Meito (from Mucor pusillus), Suparen (from Endothia parasitica) and Milcozyme (from Bacillus polymyxa) were also used in comparison with rennet for the manufacture of Cheddar-type, Tilsit (a Polish semi-hard cheese) and Kortowski cheeses. Cheeses made with Suparen and Meito were slightly bitter, while Milcozyme was found to be unsuitable for cheese manufacture (Reps et al, 1974).

Bitter flavour developed during aging of Cheddar cheese manufactured with milk clotting enzyme of Rhizopus oligosporus (Rao et al, 1979) a recombinant chymosin purified from Escherichia coli $\mathrm{K}_{12}$ (Hicks et al, 1984) or as a rennet substitute. However, further cheesemaking studies conducted with dilute enzyme preparations yielded to a non-bitter Cheddar cheese which did not retain excessive amounts of protease (chymosin) (Hicks et al, 1988). Chymosin prepared with the aid of genetically engineered microorganisms such as $E$ coli, Aspergillus niger and Kluyveromyces lactis has been shown to be identical to the natural enzyme and to produce different types of cheeses (Cheddar, Colby, Edam, Gou$\mathrm{da}$, etc) which were indistinguishable from normal cheese (made with natural chymo$\sin$ ) in regard of cheese yield, texture, smell, taste and ripening (Teuber, 1990). Since bitterness is more significant in longhold cheese varieties such as Cheddar, then many potential rennet substitutes which render cheese bitter will have to be rejected.
Bacterial rennets from Endothia parasitica, Mucor miehei, and Mucor pusillus have proved sufficiently suitable for large-scale commercialisation, even if bitterness does appear particularly in some long-hold cheeses. Of these rennet substitutes, the first 2 had a greater proteolytic action on $\beta$ casein than calf rennet (Edwards and Kosikowski, 1970). Knowing that a coagulant which does not excessively hydrolyse $\beta$ casein is suitable for the production of cheeses of good quality without bitterness, Kobayashi et al (1985) evaluated the milk clotting enzyme from Irpex lacteus (IR) as a calf rennet substitute in Cheddar cheesemaking. Although IR cheese showed a slightly higher extent of proteolysis in comparison to the calf rennet control during ripening, it did not develop a bitter taste even after 6 months of ripening. IR is thus a promising rennet substitute for cheesemaking.

The use of mixtures of equal parts of calf rennet and microbial rennet (Mucor miehei protease) in Ras cheese-making caused bitterness in this Egyptian hard type cheese which persisted until the fourth month and disappeared thereafter (Mahran et al, 1976).

Use of peptidases (eg, Pseudomonas peptidase) capable of hydrolysing bitter peptides has been suggested as a possible mechanism for preventing the occurrence of bitterness, thus enabling the wider use of microbial rennets. This option has been tried for Edam cheese manufactured with a commercial rennet from Mucor miehei; cheeses were not bitter and proteolysis was more rapid in the experimental than in the control cheese (Mälkki et al, 1978).

Addition of fungal acid proteinases with $\mathrm{pH}$ optima close to the $\mathrm{pH}$ of cheese has been shown to cause excessive proteolysis, leading to bitterness (Law and Wigmore, 1982b). 


\section{Addition of proteolytic enzymes or heat-treated cells to the cheese milk or cheese slurry to accelerate cheese ripening}

The influence of commercial mixtures of proteolytic and lipolytic microbial and animal enzyme preparations added directly to cheese curd and cheese slurries to accelerate cheese ripening has been studied by many workers (Fox, 1988-1989). When microbial acid proteases were added to Cheddar cheese slurries, it led to strong bitterness; however, blending of individual lipases with proteases or peptidases before addition to cheese blends or slurries created pronounced cheese flavour with less bitterness and rancidity (Kosikowski and Iwasaki, 1975). Similarly, the incorporation of fungal protease 31000 from Aspergillus oryzae, microbial protease P-53 of Bacillus subtilis; or MY-lipase from Candida cylindracea into slurries of salted Cheddar curds did not cause the development of flavour defects (Sood and Kosikowski, 1979); it seems that as soon as bitter peptides were formed they were hydrolysed into still smaller peptides and free amino acids.

Different results were obtained when the same food-grade enzyme preparations were added to Cheddar cheese curds as powders mixed with the salt (Law and Wigmore, 1982c; Fox, 1985). Acid proteinases invariably yielded bitter cheeses with an unacceptable soft, crumbly and greasy texture (Law and Wigmore, 1982a). Neutral proteinase when added at only $0.001-$ $0.002 \%(\mathrm{w} / \mathrm{w})$ produced medium-flavoured cheese at $12^{\circ} \mathrm{C}$ in 2 instead of 4 months; addition of neutral proteinase at higher concentration resulted in bitter cheese. When Rhozyme $\mathrm{P}_{\mathrm{il}}$, a neutral protease from Aspergillus oryzae, was added to the milled curd during the manufacture of Cheddar cheese, proteolysis and bitter- ness increased with storage time and enzyme level (from $0.01-0.1 \%$ of curd weight) (Fedrick et al, 1986). These authors also found that Colby cheese prepared with a very low amount of Rhozyme $P_{\|}$developed mature cheese texture without bitterness. Cheddar cheese exhibited moderate proteolysis with extreme bitterness when it was treated with Subtilisin A, the Bacillus licheniformis alkaline proteinase, to accelerate ripening (Law and Wigmore, 1982a).

Bitterness was absent when peptidases from Pseudomonas fluorescens VTTE 8.7 were added to Edam-type cheese in conjunction with a commercial Mucor mieheitype rennet. The same enzyme preparation from Pseudomonas prevented bitterness and enhanced the ripening process of Cheddar type cheeses made with calf rennet (Mälkki, 1978; Mälkki et al, 1978, 1979). A pronounced bitter flavour developed in Ras cheese (an Egyptian hard cheese) when Maxazyme, a proteolytic and lipolytic enzyme preparation, was added to the curd before moulding to increase the rate of ripening (El Soda et al, 1985).

Addition of germinated barley extract, Neutrase (an extracellular Bacillus subtilis neutral proteinase) or a combination of both enzyme preparations to the Cheddar cheese curd yielded, in all cases, a bitter flavour defect. Although Frey et al (1986) found this off-flavour defect to be more important in the cheese made with Neutrase alone, some workers (Law and Wigmore, 1982b; Fedrick et al, 1986) observed that optimum acceleration of Cheddar cheese ripening using Rhozyme $P_{\|}$a neutral fungal protease, seemed to be accompanied by higher levels of bitterness than is the case with Neutrase. Development of a bitter taste was also observed during the ripening of a Swedish hard type cheese treated with Neutrase to accelerate the casein breakdown. It was shown that the 
simultaneous addition of heat-treated $\left(67^{\circ} \mathrm{C}\right.$ for $\left.10 \mathrm{~s}\right)$ cells of Lactobacillus helveticus could eliminate the bitter taste by accelerating the breakdown of peptides in the Swedish full-fat (Ardö and Pettersson, 1988) or low-fat (Ardö et al, 1989) hard cheeses. Addition of Rulactine (a metalloprotease from Micrococcus caseolyticus with properties close to those of Neutrase) to Saint-Paulin cheese milk also promoted early proteolysis and enhanced bitterness development (Alkhalaf et al, 1987). However, encapsulation of Neutrase into multilamellar liposomes partially avoided bitterness. Indeed, encapsulation of proteinase into liposomes has prevented further lowering of $\mathrm{pH}$ at draining by slowing down the proteolysis process which was excessive for the free proteinase, and thus produced less peptides used as substrates for microbial proteinases and peptidases to yield small peptides and amino acids (Lawrence et al, 1983; Fox, 1988). Furthermore, the enzymes retained in the curd have been progressively released in the cheese matrix after pressing. This slow but gradually accelerated proteolysis has then helped to prevent the accumulation of bitter peptides in the cheese. From these results and those obtained by Law and Wigmore (1983) on the action of exopeptidases, Alkhalaf et al (1988) came to the conclusion that entrapment of both proteinase and exopeptidase within reverse-phase evaporation vesicle liposomes could eliminate the potential defect of bitterness. The presence of exopeptidase could thus enhance the degradation of bitter peptides which released low molecular weight peptides and amino acids.

In Gouda cheese, Bartels et al (1985a, b) found that a strain of Lactobacillus helveticus, when heat-treated at $70{ }^{\circ} \mathrm{C}$ for $18 \mathrm{~s}$ or freeze-shocked (Kim et al, 1987), had a similar debittering property when added as a starter adjunct $(2 \%)$ to milk.
The same phenomenon, but to a lesser extent, was observed when heat-shocked whole cells of Lactobacillus bulgaricus were added. The reduction in bitterness intensity observed in several trials by Bartels et al (1985a, b; 1987a), and which apparently resulted from peptidase activity of the added cells, disagrees with the observations of El Soda et al (1982). Indeed, the latter workers observed that incorporation of cell-free extracts from Lactobacillus helveticus, Lactobacillus bulgaricus or Lactobacillus lactis subsp lactis into Cheddar cheese curd enhanced bitterness. In the study of Bartels et al (1987a), reduction of bitterness in cheese by certain lactobacilli was related to lower concentrations of bitter peptides, separated by gel permeation chromatography. In contrast, bitterness was not reduced by addition of heatshocked Streptococcus thermophilus 110 or Lactobacillus bulgaricus subsp jugurti ATCC 12278. According to El Abboudi et al (1991), addition of heat-shocked cells of lactobacilli to the cheese milk before renneting could contribute to the reduction of bitterness in accelerated ripening Cheddar cheese.

Accelerated ripening and reduced bitterness were noticed in Cheddar cheese prepared with $\mathrm{Lac}^{-}$mutant strains, isolated from Lactococcus lactis subsp lactis $\mathrm{C}_{2}$, added as a starter adjunct to milk (Dulley et al, 1978). However, when a cell-free extract from Lactobacillus casei was added to the curd during the manufacture of a Cheddar-type cheese, the ripening was accelerated but, unfortunately, bitter flavour developed rapidly (El Soda et al, 1981).

Before the study of Dulley (1976), attempts to accelerate cheese ripening were based mainly on the premise that proteolysis must be increased. However, Dulley (1976) observed that extra proteolysis may not be a necessary prerequisite for flavour development. Knowing that the products of 
proteolysis are normally present in excess, he thought about converting them into flavour components by adding enzymes to the cheese in order to accelerate the ripening process. For that purpose Cheddar cheese slurries, ripened for about 1 week at $30^{\circ} \mathrm{C}$, were added to the cheese curd. Used as a source of enzymes and microorganisms, the Cheddar cheese slurries were shown to shorten the ripening time of Cheddar cheese by about 1,5 month without the development of excessive bitterness.

Use of commercial starter lactococci in conjunction with Lactobacillus strains isolated from Cheddar cheese shortened the cheese ripening process (Lee et al, 1990b) and also led to an improvement of Cheddar flavour (Lemieux et al, 1989). However, certain strains of Lactobacillus caseipseudoplantarum and Lactobacillus caseirhamnosus caused bitterness in the cheese (Lee et al, 1990a).

\section{The manner of draining the curd}

Extension of the contact time between the curd and the whey reduces the curd's buffering capacity by increasing its lactose retention and its loss of phosphorus. Cheddar cheese made from such curd becomes highly acid at maturity and this leads to the development of bitterness (Czulak et al, 1969).

The production of bitter components by incubation of a bitter and a non-bitter strain of Lactococcus lactis subsp cremoris in skim milk and in various media, with and without casein, was studied by Harwalkar and Seitz (1971). They observed that when curd was separated from whey after $18 \mathrm{~h}$ ripening, further incubation resulted in considerably greater bitterness in curd than in whole ripened milk; this could be due to increased casein and cell density in the curd.

\section{Cheese manufacturing process}

As early as 1932 , Riddet et al concluded that it was possible to modify the cheese flavour simply by changing some details in the manufacturing process. Such changes produce curd of a different nature, and since the curd is the raw material of the ripening process, the whole course of the biochemical changes which subsequently occurs may be modified. A typical example of a change in the manufacturing process which induces cheese modifications is a variation in acidity at any stage of the process. Type of acid and $\mathrm{pH}$ at curd formation affect moisture, mineral content and firmness of Mozzarella cheese made by the direct acidification procedure. In this process, there is no addition of lactic starter cultures, the $\mathrm{pH}$ of milk and curd is adjusted by various acidulants (hydrochloric, phosphoric, or lactic acids) to a value which remains constant during whey syneresis (Keller et al, 1974). It was also reported by Quarne et al (1968) that Pizza cheese made by direct acidification using calf rennet developed bitterness.

Stadhouders and Hup (1975) have shown that the cumulative formation of bitter peptides was due either to the use of certain starters or to some method of cheese-making which resulted in too high a level of rennet retained in the cheese (the lower the $\mathrm{pH}$ and the lower the cooking temperature, the higher the level of rennet retained in the cheese (Holmes et al, 1977; Stadhouders et al, 1983; Creamer et al, 1985)).

Many workers have observed that the manufacturing conditions during cheesemaking markedly affect cheese flavour, 
and more specifically undesirable defects such as bitterness (Emmons et al, 1960a, Lawrence and Gilles, 1969; Delbeke and Naudts, 1970; Lowrie et al, 1972; Jago, 1974; O'Keeffe et al, 1975; Visser et al, 1983b; Berdagué and Grappin, 1988).

\section{Cooking temperature}

The final concentration of starter bacteria in the cheese and salt-in-moisture levels are known to be altered by the cheesemaking cooking temperature (Crawford, 1977). Moreover, the rate of cell division during cooking has been found to be a decisive factor in bitter flavour production (Dinesen, 1974; Nelson, 1974).

Barton (1957) found that the entire production of the culture organisms used as starters in the manufacture of Cheddar cheese from pasteurised milk is governed by the rate of cooking and the final temperature reached. Although the classification of culture strains as "bitter" or "non-bitter" is arbitrary, it is more specifically related to cooking temperature used during cheesemaking (Lowrie and Lawrence, 1972). In all the experiments conducted by Lowrie et al (1972), Cheddar cheese was bitter when the standard cooking temperature, reduced from 37.8 to $33.3^{\circ} \mathrm{C}$, permitted either bitter or non-bitter strains to grow to a high population in the curd. Conversely, when starter growth was limited, bitterness was absent or of reduced intensity in the cheese. These observations led to the conclusion that starter bacteria had a direct role in the development of bitterness in Cheddar cheese. Later, Jago (1974) suggested that the formation of bitter peptides could proceed at a much faster rate than their degradation to non-bitter products. According to Nelson (1974), slower strains exhibited higher rates of cell division and yielded a bitter cheese (Lowrie et al, 1974) when used in experimental cheese manufacture in which the cooking temperature was lower than normal. On the other hand, a lower rate of cell division was recorded for faster growing strains used at a higher cooking temperature than normal; the resulting cheese exhibited low levels of bitter flavour.

The cooking temperature used during the manufacture of Gouda cheese was suspected by Stadhouders (1974) to control the amount of rennet retained in the curd and thus to influence the development of bitterness in the cheese. At cooking temperatures above $35^{\circ} \mathrm{C}\left(35-39^{\circ} \mathrm{C}\right)$ less rennet was found in Gouda cheese, which then had a reduced bitter flavour (Stadhouders and Hup, 1975). However, according to Martley (1975a) Stadhouder's suggestion does not seem to apply to Camembert cheese.

\section{Ripening temperature}

As reported by Law et al (1979), maturation temperature was the most important factor in determining the flavour intensity of Cheddar cheese made with Lactococcus lactis subsp cremoris NCDO 924 or 1986, either in enclosed (excluding non-starter flora) or open vats. Cheeses ripened at $13^{\circ} \mathrm{C}$ for 6 months developed a stronger flavour with less bitterness than those ripened at $6^{\circ} \mathrm{C}$ for 9 months, irrespective of the starter or vat used.

In contrast, Gouda cheese had a more bitter flavour when ripened at 16 than at $6^{\circ} \mathrm{C}$ (Stadhouders and Hup, 1975). Normal ripening temperatures for Gouda cheese being $12-13^{\circ} \mathrm{C}$, the risk of bitterness occurring was found to be greater at temperatures of 15.5 and $18{ }^{\circ} \mathrm{C}$ (Stadhouders et al, 1983). 


\section{Acidity or $\mathrm{pH}$ of cheese}

Excessive acid production by the cultures used as starters is associated with bitterness (Scott, 1986). Phillips (1935) proposed to establish a relation between acidity and the development of bitter flavour at the different stages of Cheddar cheese processing. His preliminary results seemed to associate an increased bitterness in cheeses which develop acidity greater than $\mathrm{pH} 5.00$ at 4 days after making. Besides, Czulak (1959) found bitter flavour most frequently in Cheddar cheese having a pH value of less than 5.0 in the first week. Dawson and Feagan (1960) showed a definite peak of bitterness within a $\mathrm{pH}$ range of $5.2-5.3$, decreasing at greater and lower $\mathrm{pH}$ values. Similarly, Emmons et al (1962a) confirmed a dependence of bitter flavour on cheese $\mathrm{pH}$ and found it to be similar to the effect of $\mathrm{pH}$ on protein breakdown which leads to the formation of a large pool of polypeptides, including the bitter-tasting ones. They also showed that some starter strains which produced bitterness were not greatly affected by $\mathrm{pH}$ while others were very significantly affected.

According to Czulak et al (1969), when a high lactic acid level is attained rapidly, the curd does not cheddar well. Thus, cheeses from "fast-acid" vats have a low $\mathrm{pH}$, a sour and bitter flavour, a crumbly body and pale colour. However, Lawrence and Gilles (1969) concluded that a high rate of acid production per se does not result in bitter cheese. From their results it is clear that the $\mathrm{pH}$ of a cheese at 14 days is not in itself very significant with respect to potential bitterness, it is of great importance only when the "salt-in-moisture" levels lie between $4.30 \%$ and $4.90 \%$.

The results of Sullivan et al (1973) suggested that $\mathrm{pH}$ is a determining factor in the removal of bitterness by individual starter streptococci at the $\mathrm{pH}$ of ripening Cheddar cheese $(\approx 5.0)$. Similarly, Nelson (1974) reported that, in Canadian Cheddar manufactured with single strains of Lactococcus lactis subsp cremoris, bitter flavour was greater in low (pH 5.63) than in high $\mathrm{pH}(\mathrm{pH} \mathrm{6.41)}$ cheese.

\section{Salt concentration}

A close relationship between a low salt content of Cheddar cheese and a characteristic bitter flavour was mentioned as early as 1940 by Tuckey and Ruehe. However, more recently Lawrence and Gilles (1969), in agreement with the results of Stadhouders (1962), observed a decrease in bitterness in Cheddar at salt levels greater than $4.90 \%$, and more retention of the added salt in curd salted at a low acidity than at higher acidity. These observations were confirmed by Phelan et al (1973) and by Golding (1947) for Cheddar cheese prepared under conditions of high moisture content at salt concentrations $<1.6 \%$. These conditions led to extensive proteolysis, causing bitter and putrid flavours. A slight bitterness in flavour of Kaskaval, an Egyptian cheese, was also recognised by Moneib and Safwat (1972) for a salt concentration of $<4 \%$. However, this defect was not present when the salt level was between $4-5 \%$. In the same way, the results of Keller et al (1974) suggested that development of bitterness could be inhibited by increasing the salt content or by developing a mechanism for infusing the centre of Mozzarella cheese blocks with $\mathrm{NaCl}$. As observed by many workers (Stadhouders and Hup, 1975; Stadhouders et al, 1983; Visser et al, 1983a, b), salt also reduces the intensity of the bitter flavour of Gouda cheese; indeed, the higher the salt content, the lower the score for bitter flavour. 
Being able to retard the appearance of bitter flavour in cheese and to influence the formation/degradation of bitter peptides (Stadhouders et al, 1983; Visser et al, 1983c), salt must have a direct impact on the proteolytic activity of the cell wall and of the intracellular enzymes (Visser et al, 1983a). From the studies of Stadhouders et al (1983) on Gouda cheese, it was concluded that salt inhibits the formation of bitter peptides rather than masking the bitter flavour.

Since growth of lactococci was markedly inhibited at salt-in-moisture levels > $4.90 \%$, Lawrence and Gilles (1969) suspected the effect of salt to be more specific on starter, and showed that high salt-inmoisture levels reduce the incidence of bitterness in cheese manufactured with a bitter starter. This was due to the inhibition, by $\mathrm{NaCl}$, of the degradation of $\beta$-casein by the rennet and bacterial proteinases (Fox and Walley, 1971; Sullivan and Jago, 1972; Thomas and Pearce, 1981). Exterkate (1983) confirmed the essential role played by salt in the degradation of bitter peptides by the protoplast enzymes of the starter bacteria. Salt may act on the cell wall and membrane structures, in particular those of bitter strains (thus impairing the accessibility of starter enzymes), or have a direct inhibitory effect on various proteolytic enzymes (Lawrence and Gilles, 1969; Visser et al, 1983c). Salt-in-moisture levels played also a direct role in the development of bitterness in sterile buffaloes skim milk by altering the final concentration of $S$ faecalis subsp liquefaciens. Growth of this organism was thus shown to be restricted at salt levels of $8 \%$ (Hegazi, 1989).

According to Stadhouders (1962), rennet activity is optimal at $\mathrm{pH} 5.2$ and at a salt concentration of $\approx 3 \%$. However, this activity decreases sharply as the salt concentration is increased to $5 \%$. Since the solubility of paracasein is increased by the presence of salt, the substrate is then more readily available to the enzyme, and this may be responsible for the stimulating effect of salt on the rennet activity (Stadhouders, 1962). Fox and Walley (1971) have shown that the proteolysis of $\beta$-casein by rennet or by pepsin was significantly reduced by $5 \%$, and completely inhibited by $10 \% \mathrm{NaCl}$. Increments in salt concentration from 1 to $5 \%$ were also shown to inhibit the breakdown of $\beta$-casein by Lactococcus lactis subsp cremoris bitter strain HP (Sullivan and Jago, 1972). In contrast, the rate of proteolysis of $\alpha_{\mathrm{S}_{1}}$ casein was found to be maximal in the presence of $5-10 \% \mathrm{NaCl}$ (Fox and Walley, 1971). The choice of brining method greatly determines the initial salt concentration in the interior of the cheese and may therefore influence the protein degradation pattern during the ripening process (Visser, 1981).

\section{Mineral content}

Mortensen (1984) reports that ultrafiltered (UF) Quark (a non-ripened cheese) production was initially hampered by bitterness problems, which were due to the high mineral content in the retentate. Bitterness has also resulted from the presence of excess minerals in UF Cast Feta, a ripened cheese variety in which factors other than proteolysis are important for product characteristics. However, the high salt content and the addition of lipase could effectively mask the bitterness defect (Lelievre and Lawrence, 1988).

\section{Surface moulded soft cheeses (Camembert type)}

As long as its growth is not limited, Penicillium caseicolum appears to be the princi- 
pal factor responsible for bitterness of soft body cheese such as Camembert. There are 2 ways to control the growth of this organism: 1), incubation of cheeses in a slightly ammoniacal atmosphere during the first days of ripening leads to a faster increase of the $\mathrm{pH}$ in the outer layer; and 2), some strains of Geotrichum candidum, when present in cheese milk $10.25 \%$ of the inoculum), have similar effects in reducing Penicillium growth, acid proteinase action and bitterness (Mourgues et al, 1983; Ribadeau-Dumas, 1984; Vassal and Gripon, 1984).

A study of the neutral volatile compounds in 5 different types of surface ripened cheese (Maroilles, Livarot, PontL'Évêque, Époisses and Langres) has shown the cheese to be bitter when indole produced from the degradation of tryptophan by the bacteria was present at a concentration of $10^{-3} \mathrm{ppm}$ (Dumont et al, 1974).

\section{Sanitary and hygienic packaging conditions}

Bitterness in cheese during the maturation process has been reported to result from overheating of milk during pasteurisation (Riddet et al, 1932). However, since the introduction of rigid hygiene and pasteurisation standards, the incidence of the bitter defect has still been widespread. Bitterness cannot therefore be explained entirely by the sanitary and hygiene conditions (Czulak, 1959).

As mentioned above, the development of bitterness in creamed Cottage cheese has been found to be primarily due to growth at refrigeration temperatures of psychrophilic bacteria. However, the destruction of these microorganisms and the elimination of bitterness can be achieved by the pasteurisation of the skim milk and Cottage cheese dressing (Stone and Large, 1968).

When $20 \%$ abnormal milk (from cows suffering from mastitis) was added to the cheese milk, the resulting cheese was bitter, having an unclean taste and smell and a short consistency (Sorokina and Karagueuz, 1978).

It has also been reported that poor milkcollecting and transformation hygiene, contaminated feeds or antibiotics injected into the cow might result in bitterness in cheese; thus, Gorgonzola was found to be bitter when manufactured with milk contaminated by penicillin (Delformo and Parpani, 1986).

Packaging conditions may also be responsible for the presence of bitterness in dairy products. In fact, Kosikowski and Brown (1973) have shown that gas packaging (carbon dioxide and nitrogen) was successful in preventing yeast and mould growth on creamed Cottage cheese and thus in reducing the bitter off-flavour.

\section{CONTROL OF CHEESE BITTERNESS}

The concentration of bitter peptides must exceed a certain threshold level for the bitterness to be detected in cheese. Howev$\mathrm{er}$, this threshold level has been found to be higher in old than in young cheeses. Control of bitterness in cheese, therefore, hinges on keeping the concentration of bitter peptides below the threshold level for bitter taste, either by decreasing the rate of formation of the bitter peptides, and/or by increasing the rate of their degradation to non-bitter products (Jago, 1974).

In practice, the control of bitterness in cheese can be achieved by a combination of methods which include: 1), limitation of the starter cell population; 2), maintenance 
of high-salt-in moisture levels; 3), starter pairing; 4 ), alteration of the starter culture; 5), avoidance of the use of excess rennet.

Some 20 years ago, a deficiency of the cheese grading system was pointed out; cheese made with extended time in the whey could be of acceptable quality when graded at an early stage, but yet develop serious defects on maturing. Since then standardisation of the $\mathrm{pH}$ or acidity of either the whey or the curd alone is not sufficient; it is also necessary to control the rate of acid development and the time the curd is held in the whey (Czulak et al, 1969).

Manufacture of cheese by more sophisticated methods (eg addition of denatured whey proteins) may often lead to a bitter defect in the final product. Since denatured whey proteins have a stimulatory effect on the proteolytic processes and organoleptic properties of cheese, starters with strains capable of hydrolysing bitter peptides should be used to produce high-quality cheeses with added denatured whey proteins (Krasheninin et al, 1974).

Addition (at the $3 \%$ level) of sweet cow's whey to cheese milk before pasteurisation in order to increase the water holding capacity of buffalo cheese and the extent of peptide hydrolysis in slurries resulted in the disappearance of the bitterness usually found in buffalo cheese (Tuckey and AlFayadh, 1985).

Many means have been tried to accelerate cheese ripening and to replace the calf rennet due to supply shortages and variations in quality. However, a bitter defect is often noticed in the product. A controlled method for accelerated cheese ripening achieved without upsetting the flavour balance would therefore give large cost savings to the cheese industry and satisfaction to the cheese research workers. The freeze-shock treatment of lactic acid bacteria which enables addition of large num- bers of whole cells to the milk seems to be a promising method for increasing proteolysis and flavour development in cheese (Bartels et al, 1987b). Lactobacilli species and especially Lactobacillus helveticus can be applied successfully to cheeses such as Gouda to enhance flavour development at initial stages of ripening without detrimental effect on the cheese-making procedures and cheese quality (Bartels et al, $1987 a, b)$. Use of Lactobacillus casei-casei L2A in conjunction with the starter lactococci was shown to shorten the ripening period and to improve the Cheddar flavour (El Abboudi, 1990; Laleye et al, 1990). However, when compared to other Lactobacillus strains used in Cheddar cheese manufacture (Lemieux et al, 1989), Lactobacillus casei-casei L2A did not produce bitter off-flavour and was then suggested to possess debittering enzymes.

It is recommended to periodically test individual cow's milk to detect poor chymosin-coagulation characteristics; at the same time abnormal milk, which is poorly coagulated by chymosin, would also be detected. Selective breeding of lactating cows could guarantee the exclusion of poor chymosin-coagulating milk from bulk milk supplies (Okigbo, 1986).

Good hygiene and storage of milk at temperatures below $4{ }^{\circ} \mathrm{C}$ would help to limit the growth of Pseudomonas before UHT treatment and thus prevent the gelation of the product before the expiry date (Bassette et al, 1986; Dousset et al, 1988). Ultrasound imaging is a promising nondestructive technique by which microbiological deterioration of UHT base material for soft ice-cream caused by Bacillus cereus and Staphylococcus aureus, and of UHT milk by Pseudomonas fluorescens (Ahvenainen et al, 1989a, b, c) can be easily detected. This would be a new way to verify the microbiological sterility of the product. 


\section{CONCLUSION}

Because of the great variety of technological parameters and the extremely complex system of both enzymes and substrates present in the dairy products and especially in cheese, the understanding of the cheese bitter flavour defect is still of present interest. Many studies aiming to elucidate the cause of this off-flavour defect have been considered invalid because they were carried out in relatively uncontrolled conditions. The development of the aseptic vat technique has opened a door to research on the bitterness defect by allowing the problem to be divided into parts which can be investigated separately or in appropriate combinations. This kind of study, while bringing light on the role of individual enzyme systems in bitter flavour development in cheese would possibly lead to a better insight into the mechanism of cheese ripening in general and, more fundamentally, would help to understand the basics of the cheese industry in the 21 st century. Indeed, understanding the basics would allow cheese-makers to modify the composition, flavour and physical properties of cheese without creating undesirable side effects.

The second part of this review will be more concerned about the mechanism of formation of bitter peptides, their isolation, identification, composition and structure. A final point will describe ways of masking or inhibiting the bitter off-flavour defect in dairy products, more specifically in cheeses.

\section{REFERENCES}

Abo-Elnaga IG (1974) Degeneration of white cheese offered in the market. Sudan J Food Sci Technol 6, 35
Adda J, Gripon JC, Vassal L (1982) The chemistry of flavour and texture generation in cheese. Food Chem 9, 115-129

Ahvenainen R, Mattila T, Wirtanen G (1989a) UItrasound penetration through different packaging materials. - A non-destructive method for quality control of packed UHT milk. Lebensm Wiss Technol 22, 268-272

Ahvenainen R, Wirtanen G, Manninen M (1989b) Ultrasound imaging. - A nondestructive method for control of the microbiological quality of aseptically packed foodstuffs. Lebensm Wiss Technol 22, 273-278

Ahvenainen R, Wirtanen G, Manninen M (1989c) Ultrasound imaging. - A nondestructive method for monitoring the microbiological quality of aseptically-packed milk products. Lebensm Wiss Technol 22, 382386

Alkhalaf W, Vassal L, Desmazeaud MJ, Gripon JC (1987) Utilisation de Rulactine en tant qu'agent d'affinage dans des fromages à pâte pressée. Lait $67,173-185$

Alkhalaf W, Piard JC, El Soda M, Gripon JC, Desmazeaud M, Vassal L (1988) Liposomes as proteinase carriers for the accelerated ripening of Saint-Paulin type cheese. J Food Sci 53, 1674-1679

Ardö Y, Pettersson HE (1988) Accelerated cheese ripening with heat treated cells of Lactobacillus helveticus and a commercial proteolytic enzyme. J Dairy Res 55, 239-245

Ardö $\mathrm{Y}$, Larsson PO, Lindmark Mansson $\mathrm{H}$, Hedenberg A (1989) Studies of peptidolysis during early maturation and its influence on lowfat cheese quality. Milchwissenschaft 44, 485-490

Banks JM (1988) Elimination of the development of bitter flavour in Cheddar cheese made from milk containing heat-denatured whey protein. J Soc Dairy Technol 41, 37-41

Banks JM, Stewart G, Muir DD, West IG (1987) Increasing the yield of Cheddar cheese by the acidification of milk containing heatdenatured whey protein. Milchwissenschaft $42,212-215$

Barbosa M, Valles E, Vassal L, Mocquot G (1976) L'utilisation d'extrait de Cynara cardunculus $\mathrm{L}$ comme agent coagulant en fabrication de fromages à pâte molle et à pâte cuite. Lait 56, 1-17 
Bartels HJ, Johnson ME, Olson NF (1985a) Accelerated ripening of Gouda cheese. 1. Effect and evaluation of thermophilic lactobacilli and streptococci on proteolysis and flavor development. J Dairy Sci 68 (suppl 1), 69-70

Bartels HJ, Johnson ME, Olson NF (1985b) Accelerated ripening of Gouda cheese. 2. Effect of freeze-treated Lactobacillus helveticus on proteolysis and flavor development. J Dairy Sci 68 (suppl 1), 70

Bartels HJ, Johnson ME, Olson NF (1987a) Accelerated ripening of Gouda cheese. 1. Effect of heat-shocked thermophilic lactobacilli and streptococci on proteolysis and flavor development. Milchwissenschaft 42, 83-88

Bartels HJ, Johnson ME, Olson NF (1987b) Accelerated ripening of Gouda cheese. 2. Effect of freeze-shocked Lactobacillus helveticus on proteolysis and flavour development. Milchwissenschaft 42, 139-144

Barton LB (1957) A modification of the Cheddar cheese process and its influence on selected chemical and physical properties of the cheese. Milk Prod J 48, 11-12 \& 39-41

Bassette R, Fung DYC, Mantha VR (1986) Offflavors in milk. CRC Crit Rev Food Sci Nutr $24,1-52$

Berdagué JL, Grappin R (1988) Affinage et qualité du gruyère de Comté. VI. Caractéristiques sensorielles des fromages. Lait 68, 189-204

Biede SL, Hammond EG (1979) Swiss cheese flavor. II. Organoleptic analysis. J Dairy Sci 62, 238-248

Champion HM, Stanley DW (1982) HPLC separation of bitter peptides from Cheddar cheese. Can Inst Food Sci Technol J 15, 283-288

Chapman HR, Sharpe ME, Law BA (1976) Some effects of low-temperature storage of milk on cheese production and Cheddar cheese flavour. Dairy Ind Int 41, 42-45

Charalambous G (1986) Handbook of Food and Beverage Stability. Chemical, Biochemical, Microbiological and Nutritional Aspects. Academic Press, St-Louis

Chavarri FJ, de Paz M, Nuñez M (1988) Optimization of fermentation parameters for the production of concentrated starters from non bitter Streptococcus lactis INIA 12. J Food Sci $53,1854-1857$
Cheftel JC, Cheftel H, Besançon P (1977) Introduction à la Biochimie et à la Technologie des Aliments. Technique et Documentation, Entreprise Moderne d'Édition, Paris, vol 2

Choisy C, Lenoir J, Tourneur C, Guéguen M, Juras M, Rivault D (1978) Essai de caractérisation des streptocoques lactiques au regard de l'amertume des fromages. In: XX Int Dairy Congr (brief communications) E, 498-499

Choisy C, Desmazeaud M, Gripon JC, Lamberet G, Lenoir J, Tourneur C (1984) Les phénomènes microbiologiques et enzymatiques et la biochimie de l'affinage. In: Le Fromage (Eck A, ed) Technique et Documentation, Diffusion Lavoisier, Paris

Christensen TMIE, Kristiansen KR, Madsen JS (1989) Proteolysis in cheese investigated by high performance liquid chromatography. J Dairy Res 56, 823-828

Clegg KM, Lim CL, Manson W (1974) The structure of a bitter peptide derived from casein by digestion with papain. J Dairy Res 41, 283287

Crawford RJM (1977) Introduction to discussion on bitterness in cheese. Int Dairy Fed Annu Bull 97

Creamer LK (1975) $\beta$-casein degradation in Gouda and Cheddar cheese. J Dairy Sci 58, 287-292

Creamer LK (1978) Degradation of casein components during cheese ripening. In: Fifth International Congress of Food Science and Technology. Kyoto, Japan (abstr), 57

Creamer LK (1979) Chemical aspects of food quality. In: Developments in Food Science: 2. Proceedings of the Fifth International Congress of Food Science and Technology, Kyoto, Japan (Chiba H, Fujimaki M, Iwai K, Mitsuda H, Morita Y, eds) Elsevier, Amsterdam, 340-346

Creamer LK, Lawrence RC, Gilles J, Humphries MA (1970) Bitterness in cheese: role of starter demonstrated by computed statistics. NZJ Dairy Sci Technol 5, 35

Creamer LK, Lawrence RC, Gilles J (1985) Effect of acidification of cheese milk on the resultant Cheddar cheese. NZJ Dairy Sci Technol 20, 185-203

Creamer LK, lyer M, Lelievre J (1987) Effect of various levels of rennet addition on characteristics of Cheddar cheese made from ultra- 
filtered milk. NZJ Dairy Sci Technol 22, 205214

Czulak J (1959) Bitter flavour in cheese. Aust $J$ Dairy Technol 14, 177-179

Czulak J, Conochie J, Sutherland BJ, van Leeuwen HJM (1969) Lactose, lactic acid and mineral equilibria in Cheddar cheese manufacture. J Dairy Res 36, 93-101

Dawson DJ, Feagan JT (1960) Bitter flavours in cheese. Aust J Dairy Technol 15, 65-66

Deane DD (1951) Preliminary studies of the effect of acido-proteolytic organisms and temperatures of curing on the ripening of Cheddar cheese made from pasteurized milk. J Dairy Sci 34, 776-783

Deane DD, Dolan ET (1973) Curing of cheese with reduced fat content. J Dairy Sci 56, 631633

Delbeke R, Naudts M (1970) La fabrication de fromage de Herve à partir de lait cru. Rev Agric 2, 333-355

Delformo G, Parpani G (1986) Bitter flavours in cheese. Mondo Latte 40, 565-567

Desmazeaud M (1983) Comment les bactéries lactiques se comportent-elles dans le lait ? Tech Lait 976, 11-18

Desmazeaud MJ, Gripon JC (1977) General mechanism of protein breakdown during cheese ripening. Milchwissenschaft 32, 731734

Dinesen N (1974) The real value of cheese coagulants. Dairy Ice Cream Field 157, 78-80

Dousset $X$, Demaimay M, Ravaud C, Levesque A, Pinet X, Kergo Y (1988) Influence de la température de réfrigération du lait sur la protéolyse et l'amertume du lait UHT au cours de son stockage. Lait 68, 143-156

Dulley JR (1976) The utilization of cheese slurries to accelerate the ripening of Cheddar cheese. Aust J Dairy Technol 31, 143-148

Dulley JH, Brooks DEJ, Grieve PA (1978) Utilisation possible de levains ne fermentant pas le lactose pour accélérer la maturation du fromage et méthode pour les détecter dans le fromage. In: $X X$ Int Dairy Congr (brief communications) F, 492-493

Dumont JP, Roger S, Adda J (1974) Étude des composés volatils neutres présents dans les fromages à pâte molle et à croûte lavée. Lait $54,31-43$
Dunn HC, Lindsay RC (1985) Evaluation of the role of microbial Strecker-derived aroma compounds in unclean-type flavors of Cheddar cheese. J Dairy Sci 68, 2859-2874

Edwards JL Jr, Kosikowski FV (1970) Electrophoretic proteolytic patterns in Cheddar cheese by rennet and fungal rennets: their significance to international classification of cheese varieties. J Dairy Sci 52, 1675-1678

Edwards JL Jr, Kosikowski FV (1983) Bitter compounds from Cheddar cheese. I Dairy Sci $66,727-734$

El Abboudi M (1990) Développement d'un procédé de maturation accélérée du fromage Cheddar. Master's thesis, université Laval, Quebec, Canada

El Abboudi M, Pandian S, Trépanier G, Simard RE, Lee BH (1991) Heat-shocked lactobacilli for acceleration of Cheddar cheese ripening. J Food Sci 56, 948-949, 953

El Soda M, Desmazeaud MJ, Aboudonia S, Kamal N (1981) Acceleration of cheese ripening by the addition of whole cells or cell free extracts from Lactobacillus casei to the cheese curd. Milchwissenschaft 36, 140-142

El Soda M, Desmazeaud MJ, Aboudonia S, Badran A (1982) Acceleration of cheese ripening by the addition of extracts from Lactobacillus helveticus, Lactobacillus bulgaricus and Lactobacillus lactis to the cheese curd. Milchwissenschaft 37, 325-327

El Soda M, Hussein S, Ezzat N (1985) Acceleration of Ras cheese ripening with commercial enzyme preparations. J Dairy Sci 68 (suppl 1), 71

Emmons DB, McGugan WA, Elliott JA (1960a) Effect of strain of starter culture and manufacturing procedure on bitterness in Cheddar cheese. J Dairy Sci 43, 861-862

Emmons DB, McGugan WA, Elliott JA (1960b) Nitrogen distribution in Cheddar cheese as related to bitterness and strain of starter culture. J Dairy Sci 43, 862

Emmons DB, McGugan WA, Elliott JA, Morse PM (1961) Effect of combining single-strain cultures as cheese starter on bitter flavor in Cheddar cheese at 6 months of age. $J$ Dairy Sci 44,1157

Emmons DB, McGugan WA, Elliott JA, Morse PM (1962a) Effect of strain of starter culture and of manufacturing procedure on bitter- 
ness and protein breakdown in Cheddar cheese. J Dairy Sci 45, 332-342

Emmons DB, McGugan WA, Elliott JA, Morse PM (1962b) Effect of combining single-strain cultures as cheese starter on bitterness in Cheddar cheese at six months of age. J Dairy Sci 45, 595-600

Exterkate FA (1976) Comparison of strains of Streptococcus cremoris for proteolytic activities associated with the cell wall. Neth Milk Dairy J 30, 95-105

Exterkate FA (1983) The proteolytic system of starter streptococci: the crucial point in cheesemaking. Neth Milk Dairy J 37, 94-96

Exterkate FA, Stadhouders J (1971) Pyrrolidone carboxylyl peptidase activity in bitter and non-bitter strains of Streptococcus cremoris. Neth Milk Dairy J 25, 240-245

Fedrick IA, Aston JW, Nottingham SM, Dulley JR (1986) The effect of a neutral fungal protease on Cheddar cheese ripening. NZJ Dairy Sci Technol 21, 9-19

Fox PF (1985) Developments in Dairy Chemistry: 3. Elsevier, NY

Fox PF (1988) Rennets and their action in cheese manufacture and ripening. Biotechnol Appl Biochem 10, 522-535

Fox PF (1988-1989) Acceleration of cheese ripening. Food Biotechnol (NY) 2, 133-185

Fox PF, Walley BF (1971) Influence of sodium chloride on the proteolysis of casein by rennet and by pepsin. J Dairy Res 38, 165-170

Frey JP, Johnson ME, Marth EH (1986) Peptidases and proteases in barley extract: a potential source of enzymes for use in cheese ripening. Milchwissenschaft 41, 488-489

Fryer TF (1969) Microflora of Cheddar cheese and its influence on cheese flavour. Dairy Sci Abstr 31, 471-490

Fujimaki M, Yamashita M, Okazawa Y, Arai S (1970) Applying proteolytic enzymes on soybean. 3. Diffusable bitter peptides and free amino acids in peptic hydrolysate of soybean protein. J Food Sci 35, 215-218

Gavron H, Lück H, Van der Merwe NL (1982) The manufacture of cheese using genetically modified starter culture. S Afr J Dairy Technol 14, 153-157
Gebre-Egziabher A, Humbert ES, Blankenagel G (1980) Hydrolysis of milk proteins by microbial enzymes. J Food Prot 43, 709-712

Golding NS (1947) Bitter flavor in American Cheddar cheese made from pasteurized milk. Wash State Coll Inst Dairy Proc 16, 146-150

Gordon DF Jr, Speck ML (1965) Bitterness in milk cultures of Streptococcus cremoris. $J$ Dairy Sci 48, 499-500

Green ML, Valler MJ, Kay J (1984) Assessment of the suitability for Cheddar cheesemaking of purified and commercial chicken pepsin preparations. J Dairy Res 51, 331-340

Grieve PA, Dulley JR (1983) Use of Streptococcus lactis lac- mutants for accelerating Cheddar cheese ripening. 2 . Their effect on the rate of proteolysis and flavour development. Aust J Dairy Technol 38, 49-54

Gripon JC, Desmazeaud MJ, Le Bars D, Bergère JL (1975) Étude du rôle des microorganismes et des enzymes au cours de la maturation des fromages. II. Influence de la présure commerciale. Lait 55, 502-516

Guigoz Y, Solms J (1974) Isolation of a bitter tasting peptide from "Alpkäse", a Swiss Moutain-cheese. Lebensm Wiss Technol 7, 356357

Hamilton JS, Hill RD, Van Leeuwen H (1974) A bitter peptide from Cheddar cheese. Agric Biol Chem 38, 375-379

Hansen HC, Bendixen HA, Theophilus DR (1933) Influence of different starters on the quality of Cheddar cheese. J Dairy Sci 16, 121-127

Harris WC, Hammer BW (1940) Effect of various bacteria on flavor of Cheddar cheese made from pasteurized milk. J Dairy Sci 23, 701708

Harwalkar VR, Elliott JA (1971) Isolation of bitter and astringent fractions from Cheddar cheese. J Dairy Sci 54, 8-11

Harwalkar VR, Seitz EW (1971) Production of bitter flavor components by lactic cultures. J Dairy Sci 54, 12-14

Hegazi FZ (1989) Some properties of Streptococcus faecalis subsp liquefaciens isolated from cheese with special reference to production of bitterness. Nahrung 33, 989-997 
Hicks CL, O'Leary J, Bucy J (1984) Use of recombinant chymosin in the manufacture of Cheddar cheese. J Dairy Sci 67 (suppl 1), 73

Hicks CL, Onuorah C, O'Leary J, Langlois BE (1986) Effect of milk quality and low temperature storage on cheese yield - a summation. J Dairy Sci 69, 649-657

Hicks CL, O'Leary J, Bucy J (1988) Use of recombinant chymosin in the manufacture of Cheddar and Colby cheese. J Dairy Sci 71, 1127-1131

Hillier AJ, Kanasaki M, Jago GR (1975) Effect of temperature on the growth and acid production of lactic acid bacteria. 3. The influence of added growth supplement. Aust $J$ Dairy Technol 30, 149-152

Hofi AA, El-Safty MS, Mahran GA, Khorshid MA (1976) Ripening changes in cephalotrye "Ras" cheese as affected by microbial rennet. Egypt J Dairy Sci 4, 63-70

Holmes DG, Duersch JW, Ernstrom CA (1977) Distribution of milk clotting enzymes between curd and whey and their survival during Cheddar cheese making. I Dairy Sci 60, 862-869

Huber L, Klostermeyer H (1974) Isolation of a bitter peptide from the cheese "Butterkäse" and its identification. Milchwissenschaft 29, 449-455

Hugenholtz J, Exterkate F, Konings WN (1984) The proteolytic systems of Streptococcus cremoris: an immunological analysis. Appl Environ Microbiol 48, 1105-1110

Ishibashi N, Sadamori K, Yamamoto O, Kanehisa $H$, Kouge $K$, Kikuchi E, Okai $H$, Fukui S (1987) Bitterness of phenylalanine- and tyrosine-containing peptides. Agric Biol Chem 51, 3309-3313

Ivie GW, Witzel DA, Rushing DD (1975) Toxicity and milk bittering properties of tenulin, the major sesquiterpene lactone constituent of Helenium amarum (bitter sneezeweed). J Agric Food Chem 23, 845-849

Jago GR (1962) Proteolysis of milk proteins in relation to bitter flavour in cheese. Aust $J$ Dairy Technol 17, 83-85

Jago GR (1974) Control of the bitter flavour defect in cheese. Aust J Dairy Technol 29, 9496
Jensen RG (1964) Lipolysis. J Dairy Sci 47, 210-215

Jensen JP, Reinbold GW, Washam CJ, Vedamuthu ER (1975) Role of enterococci in Cheddar cheese: organoleptic considerations. J Milk Food Technol 38, 142-145

Kalogridou-Vassiliadou D, Alichanidis E (1984) Effect of refrigerated storage of milk on the manufacture and quality of Teleme cheese. J Dairy Res 51, 629-636

Kamaly KM, Marth EH (1988) Proteinase and peptidase activities of cell-free extracts from mutant strains of lactic streptococci. I Dairy Sci 71, 2349-2357

Kaneko S, Yoneda $Y$ (1974) Studies on the cause of bitterness of yeast ripened cheese. In: XIX Int Dairy Congr (brief communications) $1 \mathrm{E}, 776$

Keller B, Olson NF, Richardson T (1974) Mineral retention and rheological properties of Mozzarella cheese made by direct acidification. J Dairy Sci 57, 174-180

Kempler GM, Baldwin KA, McKay LL, Morris HA, Halambeck S, Thorsen G (1979) Use of genetic alterations to improve Streptococcus lactis $\mathrm{C}_{2}$ as a potential Cheddar cheese starter. J Dairy Sci 62, (suppl 1), 42-43

Kikuchi T, Toyoda S (1970) Use of microbial rennets in cheesemaking. In: XVIII Int Dairy Congr 1E, 285

Kim MS, Jensen LA, Olson NF (1987) Enhancing flavor characteristics of Gouda cheese from ultrafiltered milk by addition of commercial enzyme preparations and freezeshocked Lactobacillus helveticus. J Dairy Sci 70 (suppl 1), 66

Kleter G (1976) The ripening of Gouda cheese made under strict aseptic conditions. 1. Cheese with no other bacterial enzymes than those from a starter streptococcus. Neth Milk Dairy J 30, 254-270

Klimovsky I, Zvyagintsev V, Gudkov A, Medvedeva Z (1970) Detection of "bitter" strains of lactic acid streptococci. In: XVIII Int Dairy Congr 1E, 119

Kobayashi H, Kusakabe I, Murakami K (1985) Milk-clotting enzyme from Irpex lacteus as a calf rennet substitute for Cheddar cheese manufacture. Agric Biol Chem 49, 1605-1609 
Kosikowski FV, Brown DP (1973) Influence of carbon dioxide and nitrogen on microbial populations and shelf life of Cottage cheese and sour cream. J Dairy Sci 56, 12-18

Kosikowski FV, Iwasaki T (1975) Changes in Cheddar cheese by commercial enzyme preparations. J Dairy Sci 58, 963-970

Krasheninin PF, Zvyagintsev VI, Nebert VK, Tolkachev AN (1974) Effect of whey proteins on the proteolytic process in cheese. In: XIX Int Dairy Congr (brief communications) 1E, 343

Laleye LC, Simard RE, Lee BH, Holley RA (1990) Quality attributes of Cheddar cheese containing added lactobacilli. J Food Sci 55, 114-118

Law BA, Wigmore AS (1982a) Microbial proteinases as agents for accelerated cheese ripening. J Soc Dairy Technol 35, 75-76

Law BA, Wigmore AS (1982b) Accelerated cheese ripening with food grade proteinases. J Dairy Res 49, 137-146

Law BA, Wigmore AS (1982c) Use of exogenous enzymes for accelerated ripening of Cheddar cheese. In: XXI Int Dairy Congr (brief communications), 1(2), 505

Law BA, Wigmore AS (1983) Accelerated ripening of Cheddar cheese with a commercial proteinase and intracellular enzymes from starter streptococci. J Dairy Res 50, 519-525

Law BA, Sharpe ME, Chapman HR (1976) The effect of lipolytic Gram-negative psychrotrophs in stored milk on the development of rancidity in Cheddar cheese. $J$ Dairy Res 43, 459-468

Law BA, Hosking ZD, Chapman HR (1979) The effect of some manufacturing conditions on the development of flavour in Cheddar cheese. J Soc Dairy Technol 32, 87-90

Lawrence RC, Pearce LE (1968) The case against the use of unpaired single starter strains. NZJ Dairy Sci Technol 3, 137-139

Lawrence RC, Gilles J (1969) The formation of bitterness in cheese: a critical evaluation. NZJ Dairy Sci Technol 4, 189-196

Lawrence RC, Gilles J (1971) The use of rennet in cheese-making. NZJ Dairy Sci Technol 6, 30

Lawrence RC, Gilles J (1973) Bacteriophage: the unconsidered factor in Cheddar cheese flavour. NZJ Dairy Sci Technol 8, 122-123
Lawrence RC, Creamer LK, Gilles J, Martley FG (1972) Cheddar cheese flavour. 1. The role of starters and rennets. NZJ Dairy Sci Technol 7, 32-37

Lawrence RC, Thomas TD, Terzaghi BE (1976) Reviews of the progress of dairy science: cheese starters. J Dairy Res 43, 141-193

Lawrence RC, Gilles J, Creamer LK (1983) The relationship between cheese texture and flavour. NZJ Dairy Sci Technol 18, 175-190

Lawrence RC, Heap HA, Gilles J (1984) A controlled approach to cheese technology. J Dairy Sci 67, 1632-1645

Le Bars D, Desmazeaud MJ, Gripon JC, Bergère JL (1975) Étude du rôle des microorganismes et de leurs enzymes dans la maturation des fromages. 1. Fabrication aseptique d'un caillé modèle. Lait 55, 377-389

Lebedev AB, Umanskit MS (1981) Hydrolysis of milk fat by milk lipoprotein lipase. Molochn Promst 9, 13-14, 47

Lee BH, Laleye LC, Simard RE, Holley RA, Emmons DB, Giroux RN (1990a) Influence of homofermentative lactobacilli on physicochemical and sensory properties of Cheddar cheese. J Food Sci 55, 386-390

Lee BH, Laleye LC, Simard RE, Munsch MH, Holley RA (1990b) Influence of homofermentative lactobacilli on the microflora and soluble nitrogen components in Cheddar cheese. $J$ Food Sci 55, 391-397

Lelievre J, Lawrence RC (1988) Manufacture of cheese from milk concentrated by ultrafiltration. J Dairy Res 55, 465-478

Lemieux L, Puchades R, Simard RE (1989) Size-exclusion HPLC separation of bitter and astringent fractions from Cheddar cheese made with added Lactobacillus strains to accelerate ripening. J Food Sci 54, 1234-1237

Lowrie RJ (1977) Influence of lactic streptococci on bitter flavor development in cheese. J Dairy Sci 60, 810-814

Lowrie RJ, Lawrence RC (1972) Cheddar cheese flavour. IV. A new hypothesis to account for the development of bitterness. NZJ Dairy Sci Technol 7, 51-53

Lowrie RJ, Lawrence RC, Pearce LE, Richards EL (1972) Cheddar cheese flavour. III. The growth of lactic streptococci during cheese- 
making and the effect on bitterness development. NZJ Dairy Sci Technol 7, 44-50

Lowrie RJ, Lawrence RC, Peberdy F (1974) Cheddar cheese flavour. V. Influence of bacteriophage and cooking temperature on cheese made under controlled bacteriological conditions. NZJ Dairy Sci Technol 9, 116121

Mabbitt LA, Chapman HR, Berridge NJ (1955) Experiments in cheesemaking without starter. J Dairy Res 22, 365-373

Mabbitt LA, Chapman HR, Sharpe ME (1959) Making Cheddar cheese on a small scale under controlled bacteriological conditions. J Dairy Res 26, 105-112

Mahran GA, El-Safty MS, Abdel-Hamid LB, Khorhid MA (1976) The ripening of Ras cheese as affected by the use of mixtures of animal and microbial rennets. Egypt $J$ Dairy Sci $4,13-20$

Mälkki $Y$ (1978) Ripening and debittering of cheeses and protein hydrolysates. In: Fifth Int Congr Food Sci Technol (abstr) Kyoto, 231

Mälkki Y, Mattsson R, Rouhiainen L, Karaila $P$, Ilmonen T (1976) Properties and use of a new Pseudomonas peptidase. In: Fifth International Fermentation Symposium (abstr), Berlin, 19.07

Mälkki Y, Karaila P, Antila V, Witting Ö (1978) The use of peptidases in ripening of cheese. In: Second Franco-Finnish Symposium on Biotechnology-Bioconversion in Food Technology (proceedings), Helsinki, Finland, 9195

Mälkki Y, Mattsson R, Markkanen P, Lindroth S, Karaila P (1979) Production and utilization of Pseudomonas fluorescens peptidases. In: Second International Congress on Engineering and Food and the Eight European Food Symposium (proceedings), Espoo, Finland, 282-288

Martens R (1973) Gouda cheese made with microbial rennets derived from Mucor miehei. Milchwissenschaft 28, 87-91

Martens R (1974) Utilisation de ferments concentrés congelés dans la fabrication de fromage Gouda. Rev Agric 27, 1439-1449

Martley FG (1975a) The behaviour and role of starter streptococci in Camembert cheesemaking. NZJ Dairy Sci Technol 10, 12-17
Martley FG (1975b) Comportement et rôle des streptocoques lactiques du levain en fabrication de Camembert. Lait 55, 310-323

Martley FG, Lawrence RC (1972) Cheddar cheese flavour. II. Characteristics of single strain starters associated with good or poor flavour development. NZJ Dairy Sci Technol 7, 38-44

Matoba T, Hata T (1972) Relationship between bitterness of peptides and their chemical structures. Agric Biol Chem 36, 1423-1431

McGugan WA, Howsam SG, Elliott JA, Emmons DB, Reiter B, Sharpe ME (1968) Neutral volatiles in Cheddar cheese made aseptically with and without starter culture. J Dairy Res 35, 237-245

McGugan WA, Emmons DB, Larmond E (1979) Influence of volatile and nonvolatile fractions on intensity of Cheddar cheese flavor. J Dairy Sci 62, 398-403

McKay LL, Baldwin KA (1978) Stabilization of lactose metabolism in Streptococcus lactis $\mathrm{C}_{2}$. Appl Environ Microbiol 36, 360-367

McKellar RC (1981) Development of off-flavors in ultra-high temperature and pasteurized milk as a function of proteolysis. $J$ Dairy $S c i$ $64,2138-2145$

Mills OE, Thomas TD (1980) Bitterness development in Cheddar cheese: effect of the level of starter proteinase. NZJ Dairy Sci Technol 15, 131-141

Mills OE, Thomas TD (1982) Starter proteinase and bitterness development in Cheddar cheese. In: XXI Int Dairy Congr 1 (1), 511512

Mistry VV, Kosikowski FV (1986a) Application of retentate starter produced from ultrafiltered milk to the manufacture of Cheddar cheese. J Dairy Sci 69, 1484-1490

Mistry VV, Kosikowski FV (1986b) Use of retentate starter produced by ultrafiltration in the manufacture of Cheddar cheese from 1.7:1 whole milk retentates. J Dairy Sci 69 (suppl 1) 79

Moir GM (1930) Pasteurised milk for Cheddar cheesemaking. I. A preliminary chemical investigation. J Dairy Res 1, 149-167

Moneib A, Safwat I (1972) Studies on improving locally manufactured Kaskaval cheese. II. Effect of waxing or packing in polyethylene sacs on the physical and chemical properties of the cheese. Agric Res Rev 50, 169-174 
Monnet V, Le Bars D, Gripon JC (1986) Specificity of a cell wall proteinase from Streptococcus lactis NCDO763 towards bovine $\beta$ casein. FEBS Microbiol Lett 36, 127-131

Mortensen BK (1984) Recent developments in the utilization of milk proteins in dairy products. In: Proceedings of the International Congress on Milk Proteins, Luxembourg, 109-119

Mourgues R, Bergère JL, Vassal L (1983) Possibilités d'améliorer les qualités organoleptiques des fromages de Camembert grâce à I'utilisation de Geotrichum candidum. Tech Lait 978, 11-15

Muysson DJ, Verrinder Gibbins AM (1989) The alteration of milk content by genetic engineering and recombinant DNA-mediated selection techniques. Can J Anim Sci 69, 517-527

Nelson JH (1974) The riddle of bitter flavor in cheese. Ital Cheese J 3, 1-4,6

Ney KH (1971) Prediction of bitterness of peptides from their amino acid composition. Z Lebensm Unters Forsch 147, 64-68

Ney KH (1979) Bitterness of peptides: amino acid composition and chain length. In: Food Taste Chemistry (Boudreau JC, ed) ACS Symp Ser 115, Washington, DC, 149-174

Nishimura T, Kato H (1988) Taste of free amino acids and peptides. Food Rev Int 4, 175-194

Nuñez M, Nuñez JA, Medina AL (1982) Freezedried concentrated starters for direct inoculation of vat milk in Manchego cheese manufacture. Milchwissenschaft 37, 328-330

Okai H (1977) Relationship between bitterness and chemical structure in synthetic peptides. In: Peptide Chemistry 1976 (Nakajima T, ed) 14th Symp Peptide Chemistry (proceedings), Hiroshima, 139-142

O'Keeffe RB, Fox PF, Daly C (1975) Proteolysis in Cheddar cheese: influence of the rate of acid production during manufacture. J Dairy Res 42, 111-122

Okigbo LM (1986) Evaluation and improvement of coagulation properties of milk for manufacturing. Ph D thesis. Diss Abstr Int B 46, 2515. Order No DA8523677

Okigbo LM, Richardson GH, Brown RJ, Ernstrom CA (1985) Casein composition of cow's milk of different chymosin coagulation properties. J Dairy Sci 68, 1887-1892
Patel GB, Blankenagel G (1972) Bacterial counts of raw milk and flavor of the milk after pasteurization and storage. J Milk Food Technol 35, 203-206

Pélissier JP, Manchon P (1976) Comparative study of the bitter taste of enzymic hydrolysates from cow, ewe and goat caseins. J Food Sci 41, 231-233

Pélissier JP, Mercier JC, Ribadeau-Dumas B (1974) Problème de l'amertume dans les fromages - résultats d'une enquête. Rev Lait Fr 325, 820-821

Perry KD, McGillivray WA (1964) The manufacture of "normal" and "starter-free" Cheddar cheese under controlled bacteriological conditions. J Dairy Res 31, 155-165

Phelan JA, Guiney J, Fox PF (1973) Proteolysis of $\beta$-casein in Cheddar cheese. J Dairy Res 40, 105-112

Phillips CA (1935) Bitter flavor in Cheddar cheese made from pasteurized milk. J Dairy Sci $18,471-472$

Polansky J (1989) Effect of dairy cow nutrition on certain blood characteristics and parameters of milk quality. Zivocisna Vyroba 34 , $491-497$

Price WV (1936) Bitter flavor in Cheddar cheese. J Dairy Sci 19, 185-190

Quarne EL, Larson WA, Olson NF (1968) Effect of acidulants and milk-clotting enzymes on yield, sensory quality, and proteolysis of Pizza cheese made by direct acidification. J Dairy Sci 51, 848-852

Raadsveld CW (1953) Bitter compounds from cheese. In: XIII Int Dairy Congr (proceedings), II (Sect II), 676-680

Rao KSN, Nand K, Srikanta S, Krishna-Swamy MA, Murthy VS (1979) Changes during manufacture and ripening of Cheddar cheese prepared with fungal rennet substitute of Rhizopus oligosporus. Nahrung 23, 621-626

Reiter B, Sharpe ME (1971) Relationship of the microflora to the flavour of Cheddar cheese. J Appl Bacterio/ 34, 63-80

Reiter B, Fryer TF, Pickering A, Chapman HR, Lawrence RC, Sharpe ME (1967) The effect of the microbial flora on the flavour and free fatty acid composition of Cheddar cheese. $J$ Dairy Res 34, 257-272 
Renz VU, Puhan Z (1975) Contribution to knowledge of factors favoring bitterness in yoghourt. Milchwissenschfat 30, 265-271

Reps A, Poznanski S, Kowalewska J, Roskosz $D$ (1974) Characteristics of ripening in cheeses made using microbial rennet substitutes. Rocz Inst Przem Mlecz 16, 5-20

Ribadeau-Dumas B (1984) Maîtrise de l'affinage des fromages de type Camembert. Lait 64, 448-468

Richardson BC, Creamer LK (1973) Casein proteolysis and bitter peptides in Cheddar cheese. NZJ Dairy Sci Technol 8, 46-51

Richardson BC, Newstead DF (1979) Effect of heat-stable proteases on the storage life of UHT milk. NZJ Dairy Sci Technol 14, 273279

Richardson GH, Ernstrom CA, Kim JM, Daly C (1983) Proteinase negative variants of Streptococcus cremoris for cheese starters. J Dairy Sci 66, 2278-2286

Riddet W, Valentine GM, Whitehead HR (1932) A starter producing bitterness in cheese. NZJ Agric 44, 32-34

Sandine WE, Daly C, Elliker PR, Vedamuthu ER (1972) Causes and control of culturerelated flavor defects in cultured dairy products. J Dairy Sci 55, 1031-1039

Sardinas JL (1972) Microbial rennets. Adv Appl Microbiol 15, 39-73

Schulz ME, Thomasow J (1970) Suitability of milk-coagulating enzymes for cheesemaking in relation to the cheese variety. In: XVIII Int Dairy Congr 1E, 321

Scott R (1972) Cheesemaking-enzymology or bacteriology? Process Biochem 7, 33-36

Scott R (1986) Cheese Making Practice. Elsevier Appl Sci Publ, Essex, UK, 2nd edn

Shinoda I, Tada M, Otagiri K, Okai H (1985) Bitter taste of Pro-Phe-Pro-Gly-Pro-lle-Pro corresponding to the partial sequence (positions 61-67) of bovine $\beta$-casein. In: Peptide Chemistry 1985: 23rd Symposium on Peptide Chemistry (proceedings), Kyoto, 287-290

Shinoda I, Okai H, Fukui S (1986a) Bitter taste of H-Val-Val-Val-Pro-Pro-Phe-Leu-OH corresponding to the partial sequence (positions $82-88$ ) of bovine $\beta$-casein, and related peptides. Agric Biol Chem 50, 1255-1260
Shinoda I, Tada M, Okai H, Fukui S (1986b) Bitter taste of H-Pro-Phe-Pro-Gly-Pro-lle-Pro$\mathrm{OH}$ corresponding to the partial sequence (positions 61-67) of bovine $\beta$-casein, and related peptides. Agric Biol Chem 50, 12471254

Shipe WF, Bassette R, Deane DD, Dunkley WL, Hammond EG, Harper WJ, Kleyn DH, Morgan ME, Nelson JH, Scanlan RA (1978) Off flavors of milk: nomenclature, standards, and bibliography. J Dairy Sci 61, 855-869

Singh J, Chander $\mathrm{H}$, Bhalerao VR, Dastur NN (1973) Studies on vegetable rennet from Withania coagulans. J Food Sci Technol 10, 16-19

Smith AE (1989) The potential allelopathic characteristics of bitter sneezeweed (Helenium amarum). Weed Sci 37, 665-669

Sood VK, Kosikowski FV (1979) Ripening changes and flavor development in microbial enzyme treated Cheddar cheese slurries. J Food Sci 44, 1690-1694

Sorokina O, Karagueuz A (1978) Désordres aseptiques non spécifiques de la glande mammaire des vaches et influence sur la composition et la qualité du lait. In: $X X$ Int Dairy Congr E, 160-161

Stadhouders J (1962) The proteolytic activity of rennet and starter bacteria in cheese with reference to bitter flavour. In: XVI Int Dairy Congr $B$ (section IV), 353-361

Stadhouders J (1974) Dairy starter cultures. Milchwissenschaft 29, 329-337

Stadhouders J, Hup G (1975) Factors affecting bitter flavour in Gouda cheese. Neth Milk Dairy J 29, 335-353

Stadhouders J, Hup G, Exterkate FA, Visser S (1983) Bitter flavour in cheese. 1. Mechanism of the formation of the bitter flavour defect in cheese. Neth Milk Dairy J 37, 157-167

Stanley DW, Emmons DB, Modler HW, Irvine DM (1980) Cheddar cheese made with chicken pepsin. Can Inst Food Sci Technol J 13, 97-102

Stone WK, Naff DM (1967) Increases in soluble nitrogen and bitter flavor development in Cottage cheese. J Dairy Sci 50, 1497-1500

Stone WK, Large PM (1968) Preventing bitter flavor development. Am Dairy Rev 30, 26-27, 85 
Sullivan JJ, Jago GR (1970a) A model for bitter peptide formation and degradation in cultured dairy products. Aust J Dairy Technol 25, 111

Sullivan JJ, Jago GR (1970b) Pyrrolidonecarboxylyl peptidase activity in Streptococcus cremoris ML 1. Aust J Dairy Technol 25, 141

Sullivan JJ, Jago GR (1972) The structure of bitter peptides and their formation from casein. Aust J Dairy Technol 27, 98-104

Sullivan JJ, Mou L, Rood JI, Jago GR (1973) The enzymic degradation of bitter peptides by starter streptococci. Aust J Dairy Technol $28,20-26$

Sullivan JJ, Schlipalius LE, Mou L, Jago GR (1974) Heat lability of starter cultures and its use in selecting potentially non-bitter strains. Aust J Dairy Technol 29, 71-74

Teuber M (1990) Production of chymosin (EC 3.4.23.4) by microorganisms and its use for cheesemaking. Int Dairy Fed Annu IDF Bull 251, 3-15

Thomas TD, Pearce KN (1981) Influence of salt on lactose fermentation and proteolysis in Cheddar cheese. NZJ Dairy Sci Technol 16, 253-259

Tittsler RP, Sanders GP, Lochry HR, Sager OS (1948) The influence of various lactobacilli and certain streptococci on the chemical changes, flavor development and quality of Cheddar cheese. J Dairy Sci 31, 716

Torrie JP, Cholette H, Froehlich DA, McKellar RC (1983) Growth of an extracellular proteinase-deficient strain of Pseudomonas fluorescens on milk and milk proteins. I Dairy Res 50, 365-374

Tuckey SL, Ruehe HA (1940) Relation of salt content to bitter flavor development in Cheddar cheese. J Dairy Sci 23, 517-518

Tuckey NK, Al-Fayadh MH (1985) Role of added dry whey and coagulant in the ripening of buffalo milk Cheddar cheese slurry. III. Total peptides. J Dairy Sci 68 (suppl 1), 91

Vassal L, Gripon JC (1984) L'amertume des fromages à pâte molle de type Camembert: rôle de la présure et de Penicillium caseicolum, moyens de la contrôler. Lait 64, 397-417

Visser FMW (1977a) Contribution of enzymes from rennet, starter bacteria and milk to proteolysis and flavour development in Gouda cheese. 1. Description of cheese and aseptic cheesemaking techniques. Neth Milk Dairy $J$ 31, 120-133

Visser FMW (1977b) Contribution of enzymes from rennet, starter bacteria and milk to proteolysis and flavour development in Gouda cheese. 2. Development of bitterness and cheese flavour. Neth Milk Dairy J 31, 188209

Visser FMW (1977c) Contribution of enzymes from rennet, starter bacteria and milk to proteolysis and flavour development in Gouda cheese. 3. Protein breakdown: analysis of the soluble nitrogen and amino acid nitrogen fractions. Neth Milk Dairy J 31, 210-239

Visser FMW (1977d) Contribution of enzymes from rennet, starter bacteria and milk to proteolysis and flavour development in Gouda cheese. 5. Some observations on bitter extracts from aseptically made cheeses. Neth Milk Dairy J 31, 265-276

Visser S (1981) Proteolytic enzymes and their action on milk proteins. A review. Neth Milk Dairy J 35, 65-88

Visser FMW, de Groot-Mostert AEA (1977) Contribution of enzymes from rennet, starter bacteria and milk to proteolysis and flavour development in Gouda cheese. 4. Protein breakdown: a gel electrophoretical study. Neth Milk Dairy J 31, 247-264

Visser S, Slangen KJ, Hup G (1975) Some bitter peptides from rennet-treated casein. A method for their purification, utilizing chromatographic separation on silica gel. Neth Milk Dairy J 29, 319-334

Visser S, Hup G, Exterkate FA, Stadhouders J (1983a) Bitter flavour in cheese. 2. Model studies on the formation and degradation of bitter peptides by proteolytic enzymes from calf rennet, starter cells and starter cell fractions. Neth Milk Dairy J 37, 169-180

Visser S, Slangen KJ, Hup G, Stadhouders J (1983b) Bitter flavour in cheese. 3. Comparative gel-chromatographic analysis of hydrophobic peptide fractions from twelve Goudatype cheeses and identification of bitter peptides isolated from a cheese made with Streptococcus cremoris strain HP. Neth Milk Dairy J 37, 181-192

Visser S, Slangen KJ, Hup G, Exterkate FA, Stadhouders J (1983c) The bitter flavour defect in cheese; some chemical and microbio- 
logical aspects. Neth Milk Dairy J 37, 250251

White CH, Marshall RT (1973a) Heat stable protease from Pseudomonas fluorescens P26 degrades ultra-high temperature pasteurized milk. J Dairy Sci 56, 624

White CH, Marshall RT (1973b) Reduction of shelf-life of dairy products by a heat-stable protease from Pseudomonas fluorescens P26. J Dairy Sci 56, 849-853

White $\mathrm{CH}$, Gillis WT, Simmler DL, Galal MK, Walsh JR, Adams JT (1978) Evaluation of raw milk quality tests. J Food Prot 41, 356360

Windlan H, Kosikowski FV (1956) The influence of milk-coagulating enzymes of nonanimal origin upon the flavor and constituents of Cheddar cheese. J Dairy Sci 39, 917-918

Yates AR, Irvine OR, Cunningham JD (1955) Chromatographic studies on proteolytic bacteria in their relationship to flavour development in Cheddar cheese. Can J Agric Sci 35, 337-343 